\title{
In Vitro and In Silico Characterization of G-Protein Coupled Receptor (GPCR) Targets of Phlorofucofuroeckol-A and Dieckol
}

\author{
Pradeep Paudel ${ }^{1,2,+} \mathbb{D}^{\mathbb{D}}$, Su Hui Seong ${ }^{1,3,+} \mathbb{\infty}$, Se Eun Park ${ }^{1,4}$, Jong Hoon Ryu ${ }^{5}$, Hyun Ah Jung ${ }^{6, *}$ \\ and Jae Sue Choi $1, * \mathbb{C}$
}

1 Department of Food and Life Science, Pukyong National University, Busan 48513, Korea; ppradeep@olemiss.edu (P.P.); shseong@hnibr.re.kr (S.H.S.); gogo1685@mail.ulsan.ac.kr (S.E.P.)

2 National Center for Natural Products Research, Research Institute of Pharmaceutical Sciences, The University of Mississippi, Oxford, MS 38677, USA

3 Natural Products Research Division, Honam National Institute of Biological Resource, Mokpo 58762, Korea

4 Department of Biomedical Science, Asan Medical Institute of Convergence Science and Technology, Seoul 05505, Korea

5 Department of Life and Nanopharmaceutical Science, Kyung Hee University, Seoul 02447, Korea; jhryu63@khu.ac.kr

6 Department of Food Science and Human Nutrition, Jeonbuk National University, Jeonju 54896, Korea

* Correspondence: jungha@jbnu.ac.kr (H.A.J.); choijs@pknu.ac.kr (J.S.C.); Tel.: +82-63-270-4882 (H.A.J.); +82-51-629-7547 (J.S.C.)

+ These authors contributed equally to this work.

check for updates

Citation: Paudel, P.; Seong, S.H.; Park, S.E.; Ryu, J.H.; Jung, H.A.; Choi, J.S. In Vitro and In Silico

Characterization of G-Protein Coupled Receptor (GPCR) Targets of Phlorofucofuroeckol-A and Dieckol. Mar. Drugs 2021, 19, 326. https:// doi.org/10.3390/md19060326

Academic Editors: Susana P. Gaudencio and Florbela Pereira

Received: 10 May 2021

Accepted: 2 June 2021

Published: 4 June 2021

Publisher's Note: MDPI stays neutral with regard to jurisdictional claims in published maps and institutional affiliations.

Copyright: (C) 2021 by the authors. Licensee MDPI, Basel, Switzerland. This article is an open access article distributed under the terms and conditions of the Creative Commons Attribution (CC BY) license (https:/ / creativecommons.org/licenses/by/ $4.0 /)$.
Abstract: Phlorotannins are polyphenolic compounds in marine alga, especially the brown algae. Among numerous phlorotannins, dieckol and phlorofucofuroeckol-A (PFF-A) are the major ones and despite a wider biological activity profile, knowledge of the G protein-coupled receptor (GPCR) targets of these phlorotannins is lacking. This study explores prime GPCR targets of the two phlorotannins. In silico proteocheminformatics modeling predicted twenty major protein targets and in vitro functional assays showed a good agonist effect at the $\alpha 2 \mathrm{C}$ adrenergic receptor $\left(\alpha_{2 C} \mathrm{AR}\right)$ and an antagonist effect at the adenosine $2 \mathrm{~A}$ receptor $\left(\mathrm{A}_{2 \mathrm{~A}} \mathrm{R}\right), \delta$-opioid receptor $(\delta$-OPR), glucagon-like peptide-1 receptor (GLP-1R), and 5-hydroxytryptamine $1 \mathrm{~A}$ receptor $\left(5-\mathrm{TH}_{1 \mathrm{~A}} \mathrm{R}\right)$ of both phlorotannins. Besides, dieckol showed an antagonist effect at the vasopressin $1 \mathrm{~A}$ receptor $\left(V_{1 \mathrm{~A}} \mathrm{R}\right)$ and PFF-A showed a promising agonist effect at the cannabinoid 1 receptor and an antagonist effect at $V_{1 A} R$. In silico molecular docking simulation enabled us to investigate and identify distinct binding features of these phlorotannins to the target proteins. The docking results suggested that dieckol and PFF-A bind to the crystal structures of the proteins with good affinity involving key interacting amino acid residues comparable to reference ligands. Overall, the present study suggests $\alpha_{2 C} A R, A_{2 A} R, \delta-O P R$, GLP-1R, 5- $\mathrm{TH}_{1 \mathrm{~A}} \mathrm{R}, \mathrm{CB}_{1} \mathrm{R}$, and $\mathrm{V}_{1 \mathrm{~A}} \mathrm{R}$ as prime receptor targets of dieckol and PFF-A.

Keywords: phhlorotannins; GPCRs; agonist; antagonist; dieckol; PFF-A; molecular docking

\section{Introduction}

G protein-coupled receptors (GPCRs) are a family of membrane receptors that regulate human pathophysiology and are the leading target class for pharmaceuticals. At present, GPCRs mediate the effect of approximately one-third of the FDA-approved drugs [1-3]. However, these drugs target mainly biogenic amine receptors, which comprise around 30 members of the GPCR family [3]. There is, therefore, an immense potential within pharmaceuticals/natural products to exploit, considering the remaining family members for which no existing ligands have been identified.

In the traditional drug development process, the high-throughput screening (HTS) approach against drug targets of choice is the very first step to uncover new drugs, which has now been augmented by the in silico method to maximize the probability of novel leads discovery. Traditional Chinese medicine (TCM) is an important research object of network 
(TCM herbs, targets, diseases, and syndromes) pharmacology, which aims to understand the network-based biological basis of complex diseases [4], and natural polyphenols are abundant in plant-based foods whose network proximity to disease proteins is predictive of the molecule's known therapeutic effects [5].

Secondary metabolites from seaweeds have gained much interest in natural drug discovery, because the marine source is a huge reservoir of natural products with significant biological activities. In addition, secondary metabolites (carotenoids, polyphenols, and polysaccharides) with numerous biological activities make them a potential source of leads. Among marine organisms, marine alga, i.e., green algae (Chlorophyta), brown algae (Phaeophyta), and red algae (Rhodophyta), are rich sources of bioactive compounds with various biological activities. These macroalgae are well known by seaweeds and have been widely recognized as food, functional food, and potential drug sources for decades. Brown algae are the largest type of seaweed and so far, scientists have identified the therapeutic potential of brown algae-derived secondary metabolites (particularly phloroglucinol-based polyphenols, known as phlorotannins) including, but not limited to antioxidant [6,7], antimicrobial [8], anti-diabetic [9], anti-Alzheimer's disease [10-12], anti-inflammatory [13], neuroprotective [14,15], anti-obesity [16], hepatoprotective [17], monoamine oxidase inhibitor [18], antihypertension [19] and anti-viral [20] activity. Ecklonia stolonifera OKAMURA (E. stolonifera) is an edible brown alga of the Laminariaceae family that is widely distributed along the Eastern and Southern Korean coast and rich in phlorotannins [19,21]. Dieckol and phlorofucofuroeckol-A (PFF-A) are common phlorotannins in E. stolonifera and in our recent study, we had reported human monoamine oxidase (hMAO) inhibition, dopamine $D_{3} R / D_{4} R$ receptor agonist effect, dopamine $D_{1} / 5$-hydroxytryptamine $1 \mathrm{~A}$ $\left(5-\mathrm{HT}_{1 \mathrm{~A}}\right) /$ neurokinin $1\left(\mathrm{NK}_{1}\right)$ receptor antagonist effect [22], and $\beta$-secretase and acetylcholinesterase inhibition by dieckol and PFF-A $[10,11]$. Nonetheless, other promising targets of these phlorotannins are yet to be identified.

Therefore, the main objectives of this study were to: (a) predict prime protein targets of dieckol and PFF-A (Figure 1) via proteocheminformatics modeling (PCM), (b) validate the PCM prediction by evaluating the modulatory effect on predicted receptors via cell-based functional GPCRs assays, and (c) look at the specific binding interactions of test ligands and target receptors via molecular docking simulation.<smiles>Oc1cc(O)cc(Oc2c(O)cc(O)c3c2Oc2c(O)cc(Oc4c(O)cc(Oc5c(O)cc(O)c6c5Oc5c(O)cc(O)cc5O6)cc4O)cc2O3)c1</smiles>

Dieckol

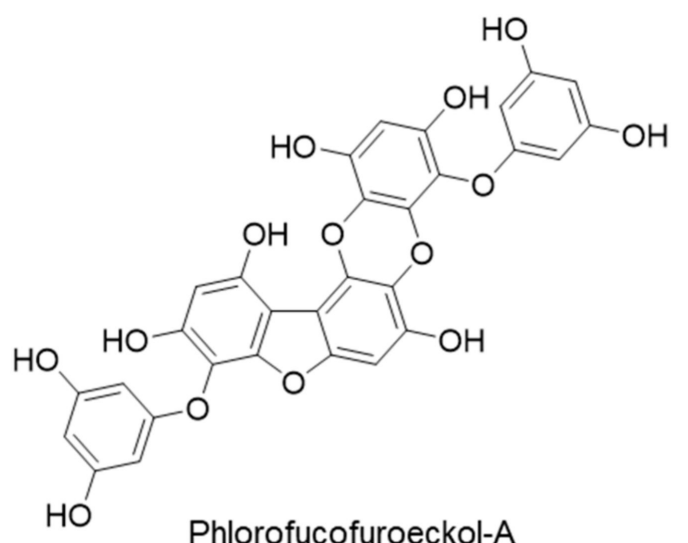

Phlorofucofuroeckol-A

Figure 1. Chemical structures of dieckol and phlorofucofuroeckol-A.

\section{Results}

2.1. In Silico Target Prediction

Proteocheminformatics (PCM) modeling is a quantitative bio-modeling technique that can predict the affinity and potency of a ligand against multiple different protein targets simultaneously by combining chemical and biological information from the ligand and related targets into a single machine learning model [23]. From in silico PCM modeling, 
the highest-ranked twenty potential protein targets were predicted for the phlorotannins. Table 1 presents a list of the target proteins with an average score value.

Table 1. List of top 20 protein targets from proteocheminformatics modeling (PCM) prediction of dieckol and phlorofucofuroeckol-A, respectively.

\begin{tabular}{|c|c|c|c|c|}
\hline \multirow{2}{*}{ Rank } & \multicolumn{2}{|c|}{ Dieckol } & \multicolumn{2}{|c|}{ Phlorofucofuroeckol-A } \\
\hline & Protein Name & Average Score & Protein Name & Average Score \\
\hline 1 & Vasopressin 1A receptor & 0.513 & Vasopressin $1 \mathrm{~A}$ receptor & 0.797 \\
\hline 2 & & & Vasopressin $1 \mathrm{~B}$ receptor & 0.742 \\
\hline 3 & & & Oxytocin receptor & 0.737 \\
\hline 4 & & & $\mathrm{~B} 2$ bradykinin receptor & 0.735 \\
\hline 5 & & & B1 bradykinin receptor & 0.727 \\
\hline 6 & & & Histamine $\mathrm{H} 1$ receptor & 0.721 \\
\hline 7 & & & Serotonin 1D receptor & 0.717 \\
\hline 8 & & & Type- 1 angiotensin II receptor & 0.716 \\
\hline 9 & & & Dopamine D2 receptor & 0.713 \\
\hline 10 & & & Cannabinoid receptor 1 & 0.711 \\
\hline 11 & & & Prostanoid EP3 receptor & 0.710 \\
\hline 12 & & & Rho-associated protein kinase 1 & 0.710 \\
\hline 13 & & & Muscarinic acetylcholine receptor M3 & 0.709 \\
\hline 14 & & & Cholecystokinin A receptor & 0.709 \\
\hline 15 & & & Serotonin 1A receptor & 0.706 \\
\hline 16 & & & Neurokinin 1 receptor & 0.706 \\
\hline 17 & & & Cysteinyl leukotriene receptor 1 & 0.706 \\
\hline 18 & & & Alpha-1D adrenergic receptor & 0.705 \\
\hline 19 & & & Cholecystokinin B receptor & 0.704 \\
\hline 20 & & & Serotonin 1B receptor & 0.704 \\
\hline
\end{tabular}

As shown in the Table 1 , the $\mathrm{V}_{1 \mathrm{~A}}$ receptor was predicted as a top target for dieckol and PFFA. For PFF-A, 5-hydroxytryptophan $1 \mathrm{~A}$ (5- $\left.\mathrm{HT}_{1 \mathrm{~A}} \mathrm{R}\right)$, 5-hydroxytryptophan $1 \mathrm{~B}\left(5-\mathrm{HT}_{1 \mathrm{~B}} \mathrm{R}\right)$, and cannabinoid $1\left(\mathrm{CB}_{1} \mathrm{R}\right)$ receptors were among the predicted top twenty protein targets. Based on this prediction and reported biological activities of the phlorotannins in the literature, we proceeded to validate adenosine $A_{2 A}$ receptor $\left(A_{2 A} R\right)$, alpha-2A adrenergic receptor $\left(\alpha_{2 A} A R\right)$, alpha- $2 C$ adrenergic receptor $\left(\alpha_{2 C} A R\right), \delta$-opioid receptor $(\delta-O P R), C B_{1} R$, free fatty acid receptor 1 (FFA ${ }_{1} \mathrm{R}$ or GPR40), glucagon-like peptide-1 receptor (GLP-1), $\mathrm{V}_{1 \mathrm{~A}} \mathrm{R}, 5-\mathrm{HT}_{1 \mathrm{~A}} \mathrm{R}$, and 5- $\mathrm{HT}_{1 \mathrm{~B}} \mathrm{R}$ cell-based functional assays.

Firstly, the functional effect of dieckol and PFF-A was screened at a $100-\mu \mathrm{M}$ concentration. As shown in Table 2, dieckol showed an agonist effect on $\alpha_{2 \mathrm{C}} \mathrm{AR}(52.4 \pm 4.24 \%)$ and $\mathrm{V}_{1 \mathrm{~A}} \mathrm{R}(106.73 \pm 2.97 \%)$ and an antagonist effect on $\mathrm{A}_{2 \mathrm{~A}} \mathrm{R}(55.55 \pm 4.03 \%), \delta$-OP $(66.95 \pm 0.92), \mathrm{CB}_{1} \mathrm{R}(158.75 \pm 17.81 \%)$, and GLP-1R $(101.0 \pm 8.20 \%)$.

Likewise, PFF-A showed an agonist effect on $\alpha_{2 C} \mathrm{AR}(83.8 \pm 0.07 \%)$ and $\mathrm{CB}_{1} \mathrm{R}(113.8$ $\pm 3.68 \%)$ and an antagonist effect on $\mathrm{A}_{2 \mathrm{~A}} \mathrm{R}(66.6 \pm 2.26 \%), \delta$-OP $(73.55 \pm 5.44)$, and GLP-1R $(105.7 \pm 1.27 \%)$. These phlorotannins were either mild active or inactive at other tested protein targets as depicted by the negative and/or low value of $\%$ stimulation or inhibition (Table 2).

Based on the functional effect above $50 \%$ at $100 \mu \mathrm{M}$, the concentration-dependent effect was further tested and compared with the reference agonists and antagonists (Figures 2 and 3 and Tables 3 and 4) followed by molecular docking simulation. Molecular docking simulation of test ligands to the crystal structures of target proteins and comparison with the reference ligands results revealed the mechanism of ligand-targetprotein interaction. 
Table 2. Agonist and antagonist effect of $100 \mu \mathrm{M}$ dieckol and phlorofucofuroeckol-A at several GPCRs.

\begin{tabular}{|c|c|c|c|c|}
\hline \multirow{3}{*}{ GPCRs } & \multicolumn{4}{|c|}{ Functional Effect at $100 \mu \mathrm{M}$ Concentration } \\
\hline & \multicolumn{2}{|c|}{ Dieckol } & \multicolumn{2}{|c|}{ Phlorofucofuroeckol-A } \\
\hline & Agonist Effect & Antagonist Effect & Agonist Effect & Antagonist Effect \\
\hline Adenosine $\mathrm{A} 2 \mathrm{~A}$ receptor $\left(\mathrm{A}_{2 \mathrm{~A}} \mathrm{R}\right)$ & $-0.1 \pm 1.41$ & $55.55 \pm 4.03$ & $-0.7 \pm 0.57$ & $66.6 \pm 2.26$ \\
\hline Alpha-2A adrenergic receptor $\left(\alpha_{2 \mathrm{~A}} \mathrm{AR}\right)$ & $13.4 \pm 19.87$ & $46.15 \pm 20.15$ & $-0.5 \pm 0.85$ & $20.95 \pm 1.77$ \\
\hline Alpha-2C adrenergic receptor $\left(\alpha_{2 C} \mathrm{AR}\right)$ & $52.4 \pm 4.24$ & $-1.2 \pm 6.08$ & $83.8 \pm 0.07$ & $19.2 \pm 9.76$ \\
\hline$\delta$-opioid receptor $(\delta$-OPR $)$ & $-5.7 \pm 0.14$ & $66.95 \pm 0.92$ & $14.7 \pm 7.35$ & $73.55 \pm 5.44$ \\
\hline Cannabinoid receptor $1\left(\mathrm{CB}_{1} \mathrm{R}\right)$ & $-23.3 \pm 12.09$ & $158.75 \pm 17.18$ & $113.8 \pm 3.68$ & $21.35 \pm 0.49$ \\
\hline Free fatty acid receptor 1 (FFA1R) (GPR40) & $0.2 \pm 1.56$ & $22.55 \pm 5.44$ & $-1.0 \pm 0.07$ & $30.15 \pm 0.78$ \\
\hline Glucagon-like peptide-1 receptor (GLP-1) & $-16.3 \pm 1.13$ & $101 \pm 8.20$ & $-15.5 \pm 2.55$ & $105.7 \pm 1.27$ \\
\hline Vasopressin $1 \mathrm{~A}$ receptor $\left(\mathrm{V}_{1 \mathrm{~A}} \mathrm{R}\right)$ & $106.73 \pm 2.97$ & $57.77 \pm 0.32^{b}$ & $38.45 \pm 7.14^{\mathrm{a}}$ & $56.90 \pm 5.37^{b}$ \\
\hline 5-hydroxytryptophan $1 \mathrm{~A}\left(5-\mathrm{HT}_{1 \mathrm{~A}} \mathrm{R}\right)$ & $1.75 \pm 0.64^{\mathrm{a}}$ & $91.0 \pm 3.11$ & $1.65 \pm 0.49^{\mathrm{a}}$ & $77.00 \pm 11.03$ \\
\hline 5-hydroxytryptophan $1 \mathrm{~B}\left(5-\mathrm{HT}_{1 \mathrm{~B}} \mathrm{R}\right)$ & & $-7.3 \pm 3.96$ & & $-18.5 \pm 2.69$ \\
\hline
\end{tabular}

${ }^{a}$ Value was extracted from our previous study [22]. ${ }^{\mathrm{b}}$ The test compound induces at least a $25 \%$ agonist effect at this concentration, which results in an apparent inhibition.
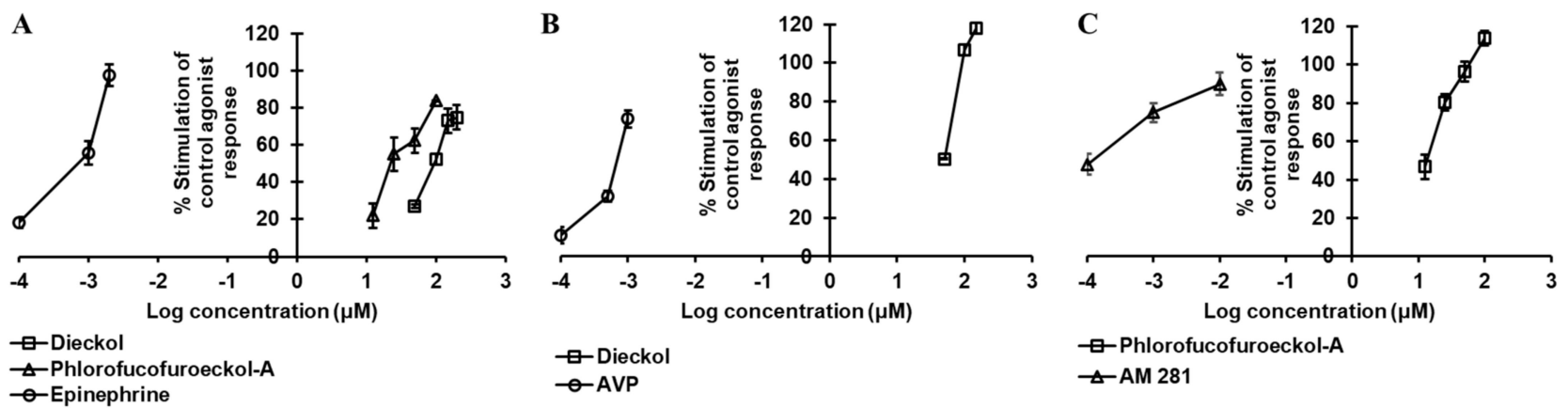

Figure 2. Dose-dependent agonist effect of dieckol and/or phlorofucofuroeckol-A on $h \alpha_{2 C} A R(A), h V_{1 A} R(B), a n d ~ h C B_{1}$ (C) receptors.
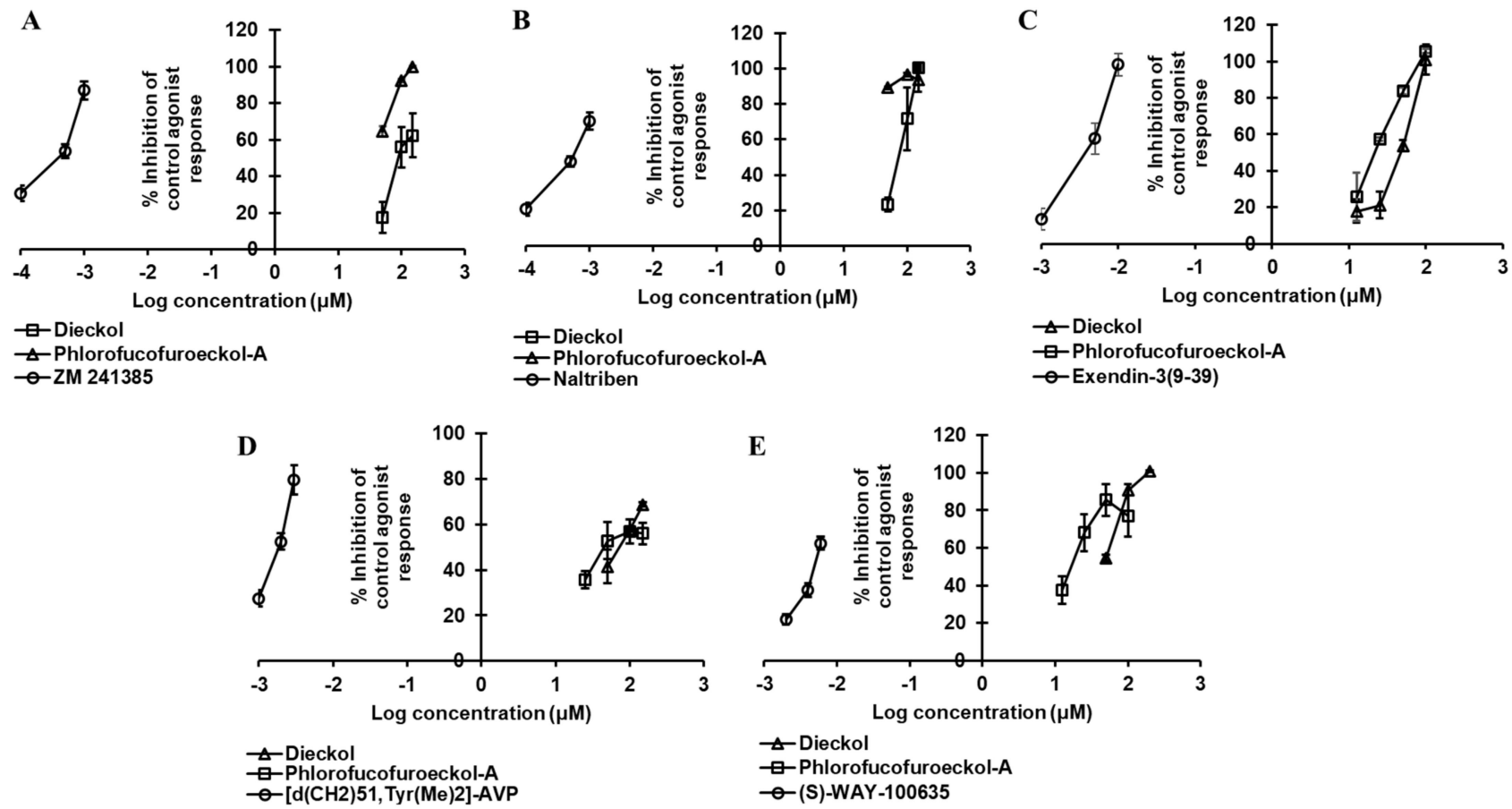

Figure 3. Dose-dependent antagonist effect of dieckol and phlorofucofuroeckol-A against hA $2 \mathrm{~A}(\mathrm{~A}), \delta$-opioid (h $\delta$-OP) (B), hGLP-1 (C), $\mathrm{hV}_{1 \mathrm{~A}} \mathrm{R}(\mathbf{D})$, and $\mathrm{h} 5-\mathrm{HT}_{1 \mathrm{~A}} \mathrm{R}(\mathbf{E})$ receptors. 
Table 3. Concentration-dependent agonist effect of dieckol and phlorofucofuroeckol-A at several GPCRs.

\begin{tabular}{|c|c|c|c|c|c|c|c|c|c|c|}
\hline \multirow{2}{*}{\multicolumn{2}{|c|}{ Compounds $(\mu \mathrm{M})$}} & \multicolumn{9}{|c|}{ Target GPCRs } \\
\hline & & $h A_{2 A} R$ & $\mathrm{~h} \alpha_{2 \mathrm{~A}} \mathrm{AR}$ & $\mathrm{h} \alpha_{2 \mathrm{C}} \mathrm{AR}$ & hס-OPR & $\mathrm{CB}_{1} \mathrm{R}$ & GPR40 & GLP-1 & $h^{\prime} V_{1 A} R$ & h5-HT ${ }_{1 \mathrm{~A}} \mathrm{R}$ \\
\hline \multirow{5}{*}{ Dieckol } & 12.5 & - & - & - & - & - & - & - & - & - \\
\hline & 50 & - & - & - & - & - & - & - & $50.40 \pm 0.42$ & - \\
\hline & 100 & $-0.1 \pm 1.41$ & $13.4 \pm 19.87$ & $52.4 \pm 4.24$ & $-5.7 \pm 0.14$ & $-23.3 \pm 12.09$ & $0.2 \pm 1.56$ & $-16.3 \pm 1.13$ & $106.73 \pm 2.97$ & $1.75 \pm 0.64^{\mathrm{c}}$ \\
\hline & 150 & - & - & $73.0 \pm 6.42$ & - & - & - & - & $118.1 \pm 2.83$ & - \\
\hline & 200 & - & - & $74.77 \pm 6.60$ & - & - & - & - & - & - \\
\hline \multicolumn{2}{|c|}{$\mathrm{EC}_{50}(\mu \mathrm{M})^{\mathrm{a}}$} & $N A$ & $N A$ & $98.80 \pm 7.71$ & $N A$ & $N A$ & $N A$ & $N A$ & $39.12 \pm 2.12$ & $N A$ \\
\hline \multirow{5}{*}{ PFF-A } & 12.5 & - & - & $22.03 \pm 6.61$ & - & $46.7 \pm 6.22$ & - & - & - & - \\
\hline & 25 & - & - & $55.0 \pm 9.13$ & - & $80.3 \pm 4.10$ & - & - & - & - \\
\hline & 50 & - & - & $62.27 \pm 6.53$ & - & $96.45 \pm 5.02$ & - & - & - & - \\
\hline & 100 & $-0.7 \pm 0.57$ & $-0.5 \pm 0.85$ & $83.8 \pm 0.07$ & $14.7 \pm 7.35$ & $113.8 \pm 3.68$ & $-1.0 \pm 0.07$ & $-15.5 \pm 2.55$ & $38.45 \pm 7.14^{\mathrm{c}}$ & $1.65 \pm 0.49^{c}$ \\
\hline & 200 & - & - & - & - & - & - & - & - & - \\
\hline \multicolumn{2}{|c|}{$\mathrm{EC}_{50}(\mu \mathrm{M})^{\mathrm{a}}$} & $N A$ & $N A$ & $23.67 \pm 3.32$ & $N A$ & $13.42 \pm 2.03$ & $N A$ & $N A$ & $N A$ & $N A$ \\
\hline \multicolumn{2}{|c|}{$\begin{array}{l}\text { Reference Drugs, } \\
\mathrm{EC}_{50}(\mathrm{nM})^{\mathrm{b}}\end{array}$} & 9.1 & 0.74 & 0.86 & 4.4 & 0.21 & 10000 & 0.049 & 0.72 & $2.5^{c}$ \\
\hline
\end{tabular}

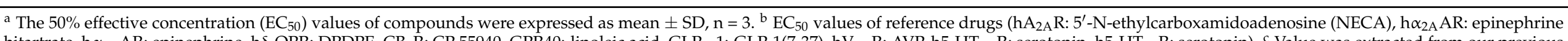

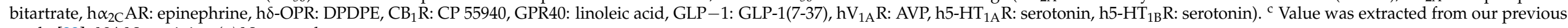
study [22]. NA No activity. (-) Not tested. 
Table 4. Concentration-dependent antagonist effects of dieckol and phlorofucofuroeckol-A at several GPCRs.

\begin{tabular}{|c|c|c|c|c|c|c|c|c|c|c|c|}
\hline \multirow{2}{*}{\multicolumn{2}{|c|}{ Compounds $(\mu \mathrm{M})$}} & \multicolumn{10}{|c|}{ Target GPCRs } \\
\hline & & $\mathbf{h} \mathbf{A}_{2 \mathrm{~A}} \mathbf{R}$ & $\mathrm{h} \alpha_{2 \mathrm{~A}} \mathrm{AR}$ & $\mathrm{h} \alpha_{2 \mathrm{C}} \mathrm{AR}$ & hઈ-OPR & $\mathrm{CB}_{1} \mathrm{R}$ & GPR40 & GLP-1 & $h_{V_{1 A}} R$ & h5-HT ${ }_{1 \mathrm{~A}} \mathrm{R}$ & h5-HT ${ }_{1 B} R$ \\
\hline \multirow{6}{*}{ Dieckol } & 12.5 & - & - & - & - & - & - & $17.87 \pm 6.32$ & - & - & - \\
\hline & 25 & - & - & - & - & - & - & $21.23 \pm 7.31$ & - & - & - \\
\hline & 50 & $17.5 \pm 8.50$ & - & - & $23.23 \pm 4.04$ & - & - & $53.80 \pm 3.12$ & $41.53 \pm 7.39^{c}$ & $54.7 \pm 1.7$ & - \\
\hline & 100 & $56.0 \pm 11.11$ & $46.15 \pm 20.15$ & $-1.20 \pm 6.08$ & $71.6 \pm 17.85$ & $-1.20 \pm 6.08$ & $22.55 \pm 5.44$ & $101.0 \pm 8.20$ & $57.77 \pm 0.32^{c}$ & $91.0 \pm 3.11$ & $-7.3 \pm 3.96$ \\
\hline & 150 & $62.43 \pm 12.19$ & - & - & $100.1 \pm 1.53$ & - & - & - & $68.80 \pm 0.85^{c}$ & - & - \\
\hline & 200 & - & - & - & - & - & - & - & - & $100.9 \pm 0.57$ & $-8.1 \pm 0.85$ \\
\hline \multicolumn{2}{|c|}{$\mathrm{IC}_{50}(\mu \mathrm{M})^{\mathrm{a}}$} & $87.18 \pm 2.63$ & $N A$ & $N A$ & $80.46 \pm 13.74$ & $N A$ & $N A$ & $47.19 \pm 2.46$ & $82.71 \pm 8.73$ & $43.31 \pm 3.22$ & $N A$ \\
\hline \multirow{5}{*}{ PFF-A } & 12.5 & - & - & - & - & - & - & $25.63 \pm 13.14$ & - & $37.40 \pm 2.19$ & - \\
\hline & 25 & - & - & - & - & - & - & $57.37 \pm 1.15$ & $35.67 \pm 3.88$ & $68.20 \pm 9.89$ & - \\
\hline & 50 & $64.7 \pm 2.72$ & - & - & $89.03 \pm 0.70$ & - & - & $83.87 \pm 2.03$ & $52.80 \pm 8.09$ & $85.55 \pm 8.41$ & - \\
\hline & 100 & $92.2 \pm 0.95$ & $20.95 \pm 1.77$ & $19.2 \pm 9.76$ & $96.47 \pm 0.84$ & $21.35 \pm 0.49$ & $30.15 \pm 0.78$ & $105.7 \pm 1.27$ & $56.90 \pm 5.37^{c}$ & $77.00 \pm 11.03$ & $-18.5 \pm 2.69$ \\
\hline & 150 & $99.93 \pm 0.31$ & - & - & $93.67 \pm 6.67$ & - & - & - & $56.07 \pm 4.72$ & - & - \\
\hline \multicolumn{2}{|c|}{$\mathrm{IC}_{50}(\mu \mathrm{M})^{\mathrm{a}}$} & $<50$ & $N A$ & $N A$ & $<50$ & $N A$ & $N A$ & $21.56 \pm 2.16$ & $42.25 \pm 0.41$ & $17.75 \pm 3.42$ & $N A$ \\
\hline \multicolumn{2}{|c|}{$\begin{array}{l}\text { Reference Drugs, } \\
\mathrm{IC}_{50}(\mathrm{nM})^{\mathrm{b}}\end{array}$} & 0.41 & 17 & 22 & 9 & 77 & $N D$ & 4.6 & 1.9 & 4.4 & 23 \\
\hline
\end{tabular}

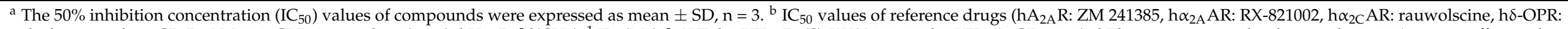

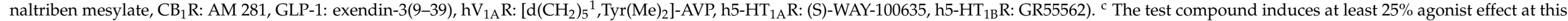
concentration, which results in an apparent inhibition. NA No activity. (-) Not tested. 


\subsection{Dieckol and PFF-A as $A_{2 A} R$ Antagonists}

Dieckol inhibited the $3 \mathrm{nM}$ epinephrine bitartrate response by $17.5 \%, 56.0 \%$, and $62.43 \%$ at a concentration of 50,100 , and $150 \mu \mathrm{M}$, respectively, and yielded an $\mathrm{IC}_{50}$ value of $87.18 \pm 2.63 \mu \mathrm{M}$ (Table 3 and Figure 3A), while PFF-A inhibited the response of the reference agonist by $64.7 \%, 92.2 \%$, and $99.93 \%$ at a concentration of 50,100 , and $150 \mu \mathrm{M}$, yielding an $\mathrm{IC}_{50}$ value $<50 \mu \mathrm{M}$ (Figure $3 \mathrm{~A}$ ).

In the docking simulation, dieckol formed two H-bond interactions with Ile80 and Asp170 (Figure 4B) while four H-bond interactions (His278, Ala59, Ala81, Ser67) were observed for PFF-A (Figure $3 \mathrm{C}$ ). The binding of reference ligands to the $\mathrm{A}_{2 \mathrm{~A}} \mathrm{R}$ crystal structure showed the involvement of residues Phe168, Leu249, Asn253, and Met270. The total number of hydrophobic and electrostatic interactions involved in dieckol binding was greater than that of PFF-A binding (Table S2). Interestingly, only one interacting residue (Leu249) was in common with the reference ligand. However, PFF-A had two common interacting residues (Leu249 and Phe168) with reference antagonist ZM241385 (Table S1).

$\mathbf{A}$

D
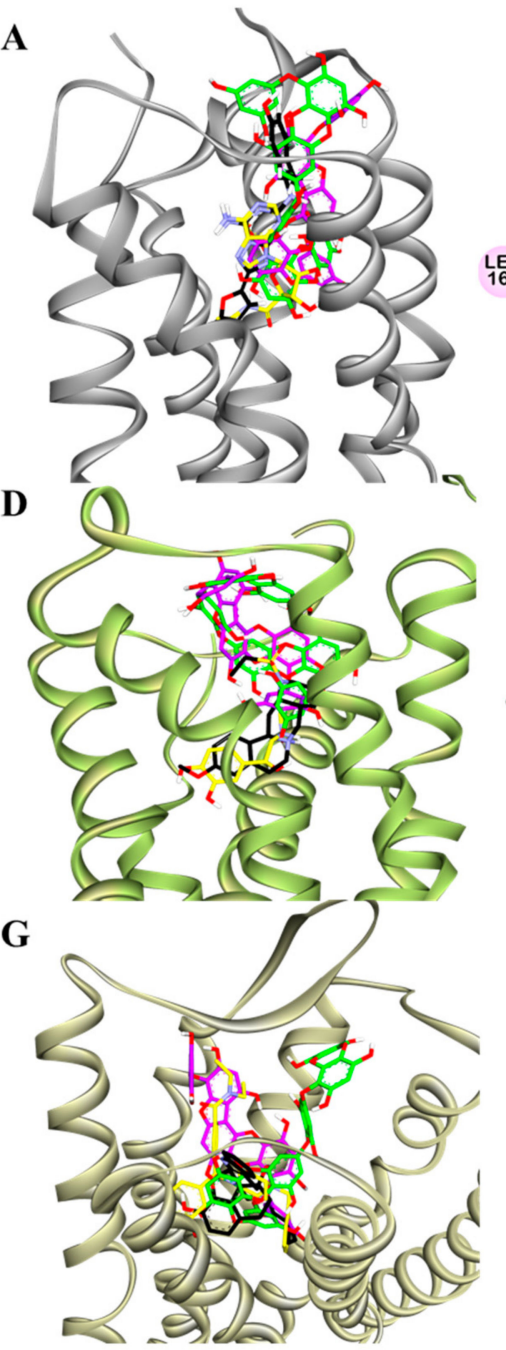

B

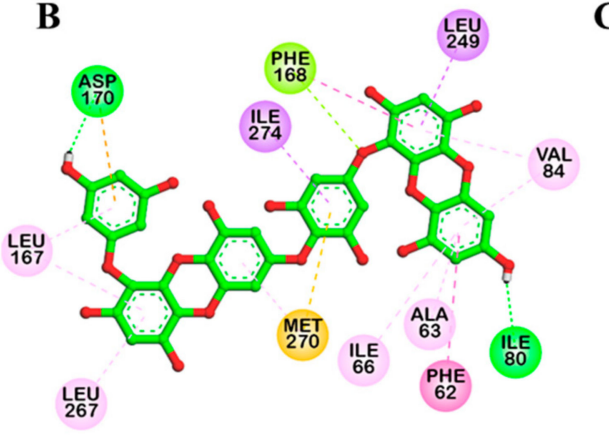

$\mathbf{E}$

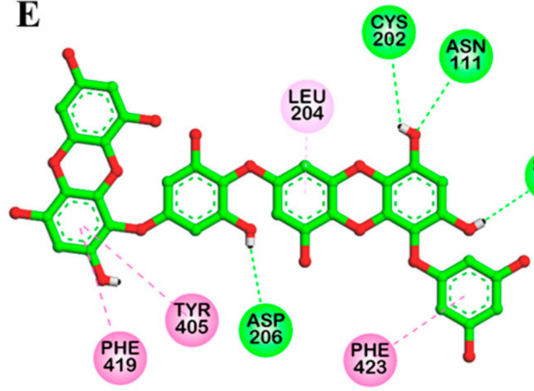

H

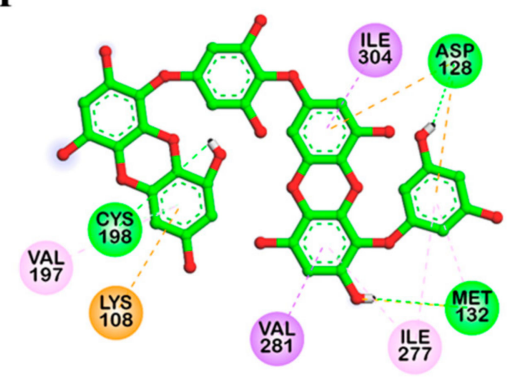

C

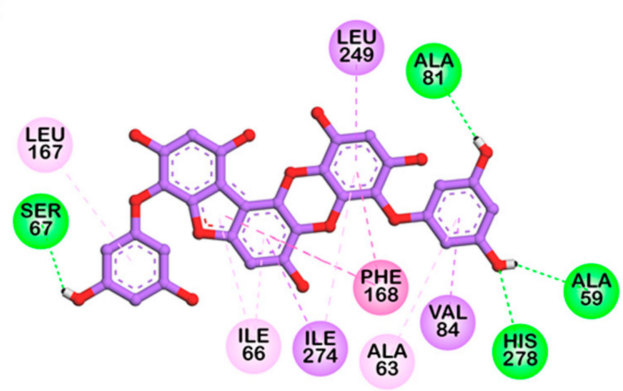

$\mathbf{F}$

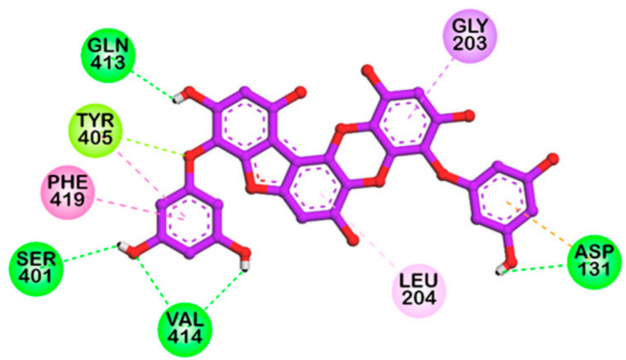

I

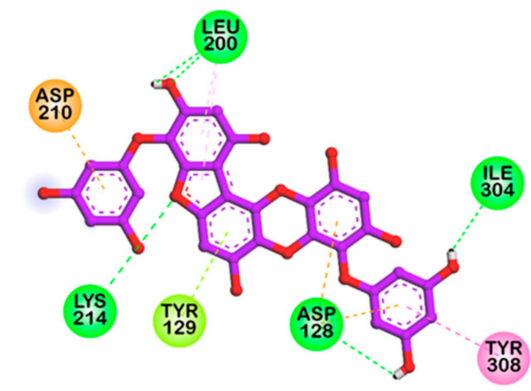

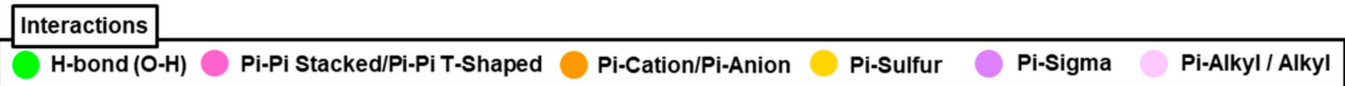

Figure 4. Molecular docking of dieckol and phlorofucofuroeckol-A in the active site of $h A_{2 A} R(A), h \alpha_{2 C} A R(D)$, and h $\delta$-OPR (G) along with reported agonist (yellow stick) and antagonist (black stick). Detailed $h \mathrm{~A}_{2 \mathrm{~A}} \mathrm{R}$-ligand (B) for dieckol and (C) for phlorofucofuroeckol-A), h $\alpha_{2 C}$ AR-ligand (E) for dieckol and (F) for phlorofucofuroeckol-A), and h $\delta$-OPR-ligand interactions (H) for dieckol and (I) for phlorofucofuroeckol-A) on a 2D diagram. 


\subsection{Dieckol and PFF-A as $\alpha_{2 C} A R$ Agonists}

Evaluation of the concentration-dependent agonist effect of phlorotannins (Table 3 and Figure $2 \mathrm{~A}$ ) at $\alpha_{2 \mathrm{C}} \mathrm{AR}$ depicted dieckol as a moderate agonist $\left(\mathrm{EC}_{50}: 98.80 \pm 7.71 \mu \mathrm{M}\right)$ and PFF-A as a good agonist $\left(\mathrm{EC}_{50}: 23.67 \pm 3.32 \mu \mathrm{M}\right)$. Even at a $25-\mu \mathrm{M}$ concentration, PFF-A stimulated the effect of $1 \mu \mathrm{M}$ epinephrine by $55 \%$. The reference agonist epinephrine had an $\mathrm{EC}_{50}$ value of $0.86 \mathrm{nM}$. To further support the functional effect and delineate the difference in activity between the two phlorotannins, a molecular docking simulation of test ligands and target protein was performed.

As shown in Figure 4D,E, dieckol interacted with Asn111, Ser108, Cys202, Asp206, and Gly203 via H-bond (Figure 2B). Similarly, PFFA also displayed four H-bond interactions with Val414, Asp131, Ser401, and Gln413 (Figure 4F). H-bond interaction with Asp131 was a typical interaction observed for the reference agonist (epinephrine) and PFF-A, but absent in dieckol binding. Between two test ligands, hydrophobic interactions with Phe419, Tyr405, and Leu204 were common (Table S1).

\subsection{Dieckol and PFF-A as $\delta$-OPR Antagonists}

The dose-dependent antagonist effect at the $\delta$-opioid receptor depicted PFF-A as a potent natural antagonist. As shown in Table 4 and Figure 3B, even at the $50-\mu \mathrm{M}$ concentration, PFF-A inhibited the effect of $25 \mathrm{nM}$ [D-Pen2, D-Pen5]enkephalin (DPDPE) by $89.03 \pm 0.70 \%$, while the effect was $23.23 \pm 4.04 \%$ for the same concentration of dieckol. Dieckol had an $\mathrm{IC}_{50}$ value of $80.46 \pm 13.74 \mu \mathrm{M}$, but the value was $<50 \mu \mathrm{M}$ for PFF-A. The reference antagonist naltriben mesylate had an $\mathrm{IC}_{50}$ value of $9 \mathrm{nM}$. The binding of dieckol to the crystal structure of 4ej4 (Figure 4G,H) showed an involvement of three Hbond interactions (Asp128, Met132, Cys198) and numerous hydrophobic and electrostatic interactions (Met132 (Sulfur-O, $\pi$-alkyl), Lys108 ( $\pi$-cation, $\pi$-Alkyl), Asp128 ( $\pi$-anion), Val281 ( $\pi$-sigma), Ile304 ( $\pi$-sigma), Cys198 ( $\pi$-sulfur), Ile277 ( $\pi$-alkyl), and Val197 $(\pi$ alkyl)). Likewise, as shown in Figure 4I, PFF-A formed four H-bond interactions with Leu200, Lys214, Ile304, and Asp128 and five hydrophobic and electrostatic interactions with Asp128 ( $\pi$-anion), Asp210 ( $\pi$-Anion), Tyr129 ( $\pi$-lone pair), Tyr308 ( $\pi$ - $\pi$ stacked), and Leu200 ( $\pi$-alkyl).

The reference antagonist naltrindole showed an H-bond interaction with aspartic acid residue (Asp128) and numerous hydrophobic interactions with tryptophan residues Trp284 ( $\pi-\pi$-T-shaped), Trp284 ( $\pi$-alkyl), and Trp274 ( $\pi$-alkyl). Only Asp128 was a common interacting residue among the test and reference ligands while Tyr308 was observed for PFF-A and reference ligand binding, but not for dieckol (Tables S1 and S2).

\subsection{PFF- $A$ as a $C B_{1}$ R Agonist}

Only PFF-A showed a full $\mathrm{CB}_{1} \mathrm{R}$ agonist effect $(113.8 \pm 3.68 \%)$ at the $100-\mu \mathrm{M}$ concentration. Therefore, the effect at lower concentrations was tested and, as shown in Table 3 and Figure 2C, PFF-A stimulated the effect of $10 \mathrm{nM} \mathrm{CP} 55940$ by $46.7,80.3$, and $96.45 \%$ at $12.5,25$, and $50 \mu \mathrm{M}$, respectively. Hence, the log concentration vs. \% simulation graph yielded an $\mathrm{EC}_{50}$ value of $13.42 \pm 2.03 \mu \mathrm{M}$. Reference agonist $\mathrm{CP} 55940$ had an $\mathrm{EC}_{50}$ value of $0.21 \mathrm{nM}$. To predict the binding affinity and characterize the binding mode of PFF-A and $\mathrm{CB}_{1} \mathrm{R}$, molecular docking simulation was performed (Figure 5A). As tabulated in Tables $\mathrm{S} 3$ and S4, PFF-A interacted with the active-state $\mathrm{CB}_{1} \mathrm{R}$ (6kqi) by forming three $\mathrm{H}$-bonds (Ser173, His178, and Met363) and numerous hydrophobic interactions-Phe177, Phe268, Trp279, Val196, Leu193, and Met363. Interactions with Ser173, Phe268, Phe177, Trp279, Val196, and Leu193 are a common observation in the binding of PFF-A and CP 55940 with the active-state $\mathrm{CB}_{1} \mathrm{R}$ (6kqi). The reference antagonist taranabant interacted with the inactive-state $\mathrm{CB}_{1} \mathrm{R}(5 \mathrm{u} 09)$ by forming hydrogen-bond interactions with Ser173, Phe189, and Lys192 via the $-\mathrm{CF}_{3}$ group. Likewise, other hydrophobic interactions involved in taranabant-5u09 binding were phenylalanine residues (Phe170, Phe174, Phe189, Phe268, and Phe379), Trp279, His178, Leu192, Leu193, Ile267, and Met363 (Figure 5B). 

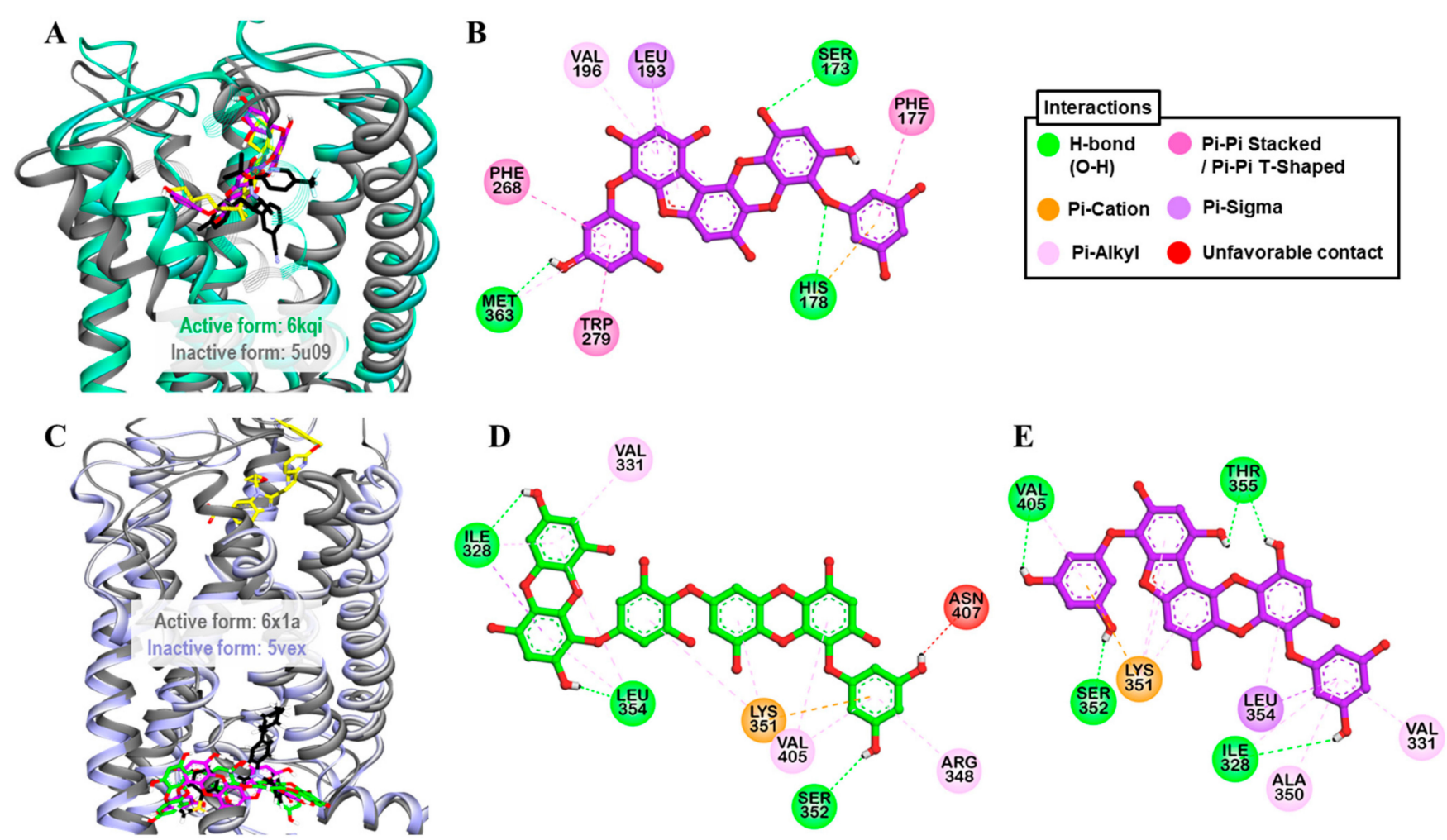

Figure 5. (A) Molecular docking of phlorofucofuroeckol-A (purple stick) in an active-state of $h \mathrm{CB}_{1} \mathrm{R}$ (PDB ID: $6 \mathrm{kqi}$ ) along with reported agonist (yellow stick). Structure of reported antagonist taranabant docked into the inactive state of $h \mathrm{CB}_{1} \mathrm{R}$ (PDB ID: 5u09, gray ribbon) is shown as black stick. (B) Detailed $h \mathrm{CB}_{1} \mathrm{R}$-ligand interactions on a $2 \mathrm{D}$ diagram for phlorofucofuroeckol-A. (C) Molecular docking of dieckol (green stick) and phlorofucofuroeckol-A (purple stick) in an inactive-state of $h$ GLP-1 (PDB ID: 5vex, blue ribbon) along with reported antagonist, NNC0640 (black stick). Structure of reported agonist PF-06882961 docked into the active-state of $h$ GLP-1 (PDB ID: 6x1a, gray ribbon) is shown as yellow stick. $(\mathbf{B}, \mathbf{C})$ Detailed $h$ GLP-1-ligand interactions on a 2D diagram (D) for dieckol and (E) for phlorofucofuroeckol-A.

\subsection{Dieckol and PFF-A as GLP-1R Antagonists}

Results from the functional assay on mouse GLP-1 receptor-expressed $\beta$ TC6 cells demonstrated dieckol and PFF-A as full antagonists of the GLP-1 receptor. At a concentration of $100 \mu \mathrm{M}$, both the compounds inhibited the effect of $0.3 \mathrm{nM}$ GLP-1(7-37) by $100 \%$. However, at the $25-\mu \mathrm{M}$ concentration, PFF-A inhibited the reference agonist-response by $57.37 \%$ and dieckol by $21.23 \%$. Additionally, a dose-dependent response curve yielded $\mathrm{IC}_{50}$ values of $47.19 \pm 2.46$ and $21.56 \pm 2.16 \mu \mathrm{M}$ for dieckol and PFF-A, respectively (Table 4 and Figure 3C). The potency of PFF-A was two-fold higher than that of dieckol. The reference antagonist exendin-3(9-39) had an $\mathrm{IC}_{50}$ value of $4.6 \mathrm{nM}$. From the molecular docking study, hydrogen-bond interactions with Ser352 and Thr355 (Table S3) and hydrophobic interactions with Leu354, Lys351, and Val405 (Table S4) were common observations in test ligands and reference antagonist NNC0640 binding with an inactive-state GLP-1R (5vex) (Figure 5C-E) in our molecular docking simulation. An unfavorable contact between dieckol and GLP-1R receptor was observed via the Asn407 residue.

\subsection{Dieckol as Agonist and PFF-A as Antagonist of $h V_{1 A} R$}

The agonist effect of dieckol at $\mathrm{V}_{1 \mathrm{~A}} \mathrm{R}$ was first tested at $100 \mu \mathrm{M}$ to compare with the effect of PFF-A that we reported earlier [22]. As tabulated in Table 2, dieckol at $100-\mu \mathrm{M}$ concentration stimulated the percentage agonist effect of $1 \mu \mathrm{M}$ arginine vasopressin (AVP) by $106.73 \pm 2.97 \%$ and inhibited the percentage of control agonist response by $57.77 \pm 0.32 \%$. In the $\mathrm{hV}_{1 \mathrm{~A}} \mathrm{R}$ antagonist assay, the $100-\mu \mathrm{M}$ concentration of dieckol induced at least a $25 \%$ agonist effect. In comparison, PFF-A induced a $38.45 \pm 7.14 \%$ stimulation and $56.90 \pm 5.37 \%$ inhibition of the control agonist response at $100 \mu \mathrm{M}$. Furthermore, the 
concentration-dependent dose-response curve depicted dieckol as a $\mathrm{hV}_{1 \mathrm{~A}} \mathrm{R}$ agonist $\left(\mathrm{EC}_{50}\right.$ : $39.12 \pm 2.12 \mu \mathrm{M})$ (Table 3 and Figure $2 \mathrm{~B}$ ) and PFF-A as an antagonist ( $\left.\mathrm{IC}_{50}: 42.25 \pm 0.41 \mu \mathrm{M}\right)$ (Table 4 and Figure 3D).

Molecular simulation of dieckol and PFF-A along with reference ligands to a crystal structure of $h V_{1 \mathrm{~A}} \mathrm{R}$ predicted that both test ligands bind with high affinity (Figure $6 \mathrm{~A}$ ). Dieckol formed H-bond interactions with Gln131, Ala334, and Asp112, and hydrophobic interactions with Lys128, Met135, Trp204, Ala101, and Ala334 (Figure 6B). Reference agonist AVP formed H-bond interactions with Asp202 (Salt-bridge), Glu54, Asp112, and Ile330 and hydrophobic interactions with Trp204, Ile330, Ala101, Ala334, Val132, and Met135. This shows that dieckol and AVP have numerous residues in common that involve binding with the receptor.

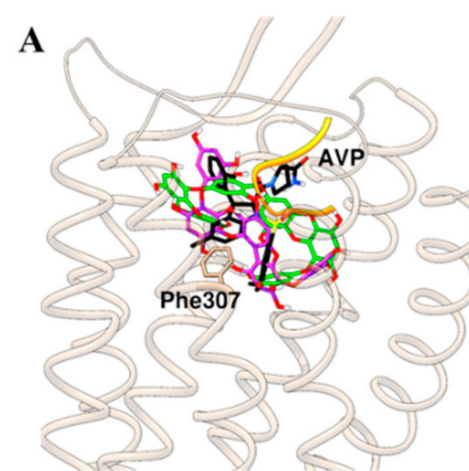

D

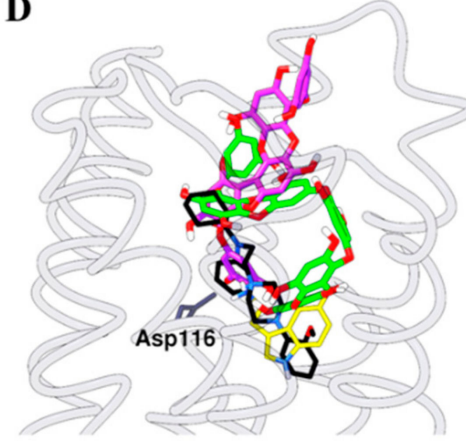

B

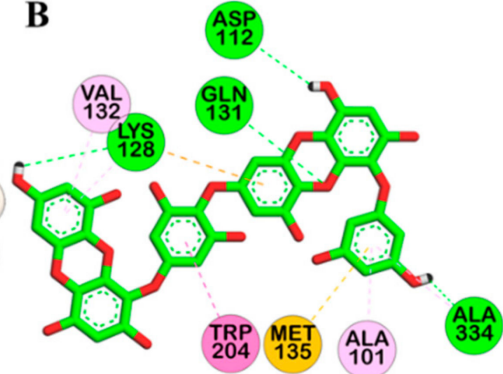

$\mathbf{E}$

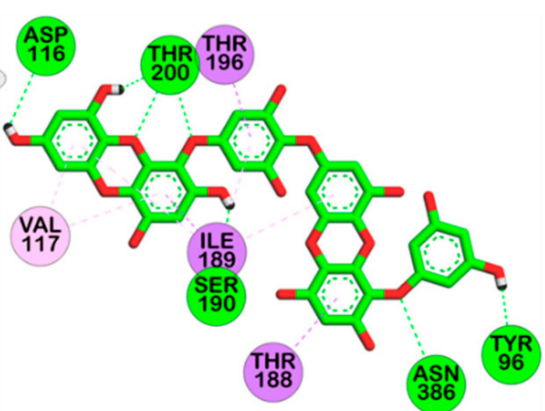

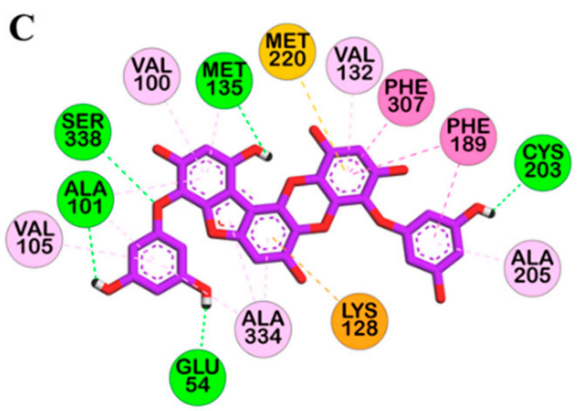

$\mathbf{F}$

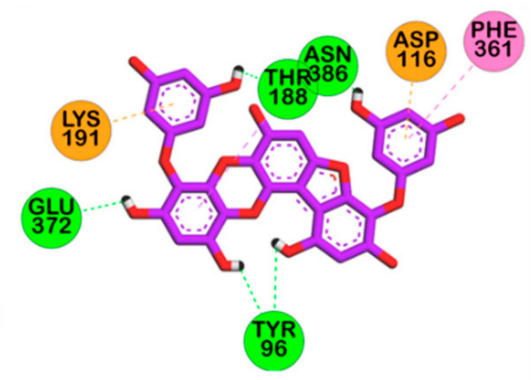

Interactions

H-bond(O-H) Pi-Pi Stacked/Pi-Pi T-Shaped Pi-Cation/Pi-Anion Pi-Sulfur $\bigcirc$ Pi-Sigma Pi-Alkyl

Figure 6. Molecular docking simulation of $\mathrm{hV}_{1 \mathrm{~A}} \mathrm{R}(\mathrm{A})$ and $\mathrm{h} 5-\mathrm{HT}_{1 \mathrm{~A}} \mathrm{R}$ (D) binding with dieckol (green stick) and phlorofucofuroeckol-A (purple stick) along with reported agonist (yellow ribbon or stick) and antagonist (black stick). Detailed $\mathrm{hV}_{1 \mathrm{~A}} \mathrm{R}$-ligand (B) for dieckol and (C) for phlorofucofuroeckol-A) and h5- $\mathrm{HT}_{1 \mathrm{~A}} \mathrm{R}$-ligand interactions (E) for dieckol and (F) for phlorofucofuroeckol-A) on a 2D diagram.

Likewise, PFF-A bound to the $\mathrm{hV}_{1 \mathrm{~A}} \mathrm{R}$ via five H-bond interactions (Ser338, Cys203, Met135, Glu54, Ala101) and other hydrophobic interactions with Lys128, Met220, Phe189, Phe307, Val132, Val100, Ala101, Met135, Ala334, Ala205, and Val105 (Figure 6C). Three H-bond interactions with Gln131, Gln108, and Lys128, and hydrophobic interactions with Phe307, Trp204, Val132, Met135, Met220, Ala334, Ala205, Gln131, and Thr333 were observed for SR49059 binding. The docking result shows that, respective to their functional effect, dieckol and PFF-A interact with residues that were involved in the binding of the reference agonist and antagonist (Tables S5 and S6).

\subsection{Dieckol and PFF-A as 5-HT $T_{1 A} R$ Antagonists}

An antagonist effect was observed for dieckol and PFF-A in a cell-based functional assay. At $100-\mu \mathrm{M}$ concentration, dieckol and PFF-A inhibited the response of $30 \mathrm{nM}$ serotonin by $91.0 \pm 3.11 \%$ and $77.00 \pm 11.03 \%$, respectively (Table 2 ). A concentration- 
dependent dose-response showed that dieckol and PFF-A inhibited the $50 \%$ response of $30 \mathrm{nM}$ serotonin at $43.31 \pm 3.22$ and $17.75 \pm 3.42 \mu \mathrm{M}$, respectively (Table 4 and Figure 3E). However, the agonist effect at $5-\mathrm{HT}_{1 \mathrm{~A}} \mathrm{R}$ was negligible for both the compounds when tested at the $100-\mu \mathrm{M}$ concentration. As a result, the $\mathrm{EC}_{50}$ value was not determined. Reference drug serotonin had an $\mathrm{EC}_{50}$ value of $0.72 \mathrm{nM}$ and antagonist GR55562 had an $\mathrm{IC}_{50}$ value of $4.4 \mathrm{nM}$.

Docking of test and reference ligands to the active site of $5-\mathrm{HT}_{1 \mathrm{~A}} \mathrm{R}$ demonstrated that aspartic acid residue Asp116 is one of the important binding residues (Figure 6D). Dieckol formed an H-bond interaction with Asp116, Thr200, Ser190, Asn386, and Tyr96 while PFF-A did with Thr188, Glu372, Tyr96, and Asn386 (Figure 6E,F). Reference ligands serotonin and WAY 100635 formed an H-bond interaction with Asp116 via a salt-bridge. Interactions with Thr200, Phe361, and Val117 were observed for test ligands and serotonin binding (Tables S5 and S6).

\section{Discussion}

Dieckol and PFF-A are phloroglucinol (1,3,5-trihydroxybenzene)-based polyphenols with a varied number of phloroglucinol units attached via dibenzofuran and dibenzodioxin linkages. Dieckol is a phloroglucinol hexamer and PFF-A is a phloroglucinol pentamer. A structure-activity relationship between phloroglucinol and its oligomers in our recent study [22] showed that more than three repeating phloroglucinol units are necessary for hMAOs inhibition and $\mathrm{D}_{3} / \mathrm{D}_{4}$ receptor agonist effect. Likewise, oligomerization of phloroglucinol with more than five repeating units is essential for the antagonist effect at $D_{1}$, $\mathrm{NK}_{1}$, and $5-\mathrm{HT}_{1} \mathrm{~A}$ receptors. Here, although the monomer phloroglucinol is not included in the study, the pentamer (PFF-A) showed better activity than a hexamer (dieckol). An interesting observation in this study is that regardless of the receptors at which these two phlorotannins showed functional effects (except the $\mathrm{hV}_{1 \mathrm{~A}} \mathrm{R}$ ), PFF-A was two-fold more potent than dieckol. In contrary to the findings that the phenolic -OH groups attached to the benzene ring of polyphenols play a vital role in the antioxidant effect [24-26] and that an increase in the number of hydroxyl groups increases antioxidant activity, the functional effect of PFF-A at tested GPCRs was higher than that of dieckol despite having a lower number of hydroxyl groups. The possible reason underlying this might be the structure or orientation of PFF-A that enables it to reach the core active site cavity of receptors where it binds to conserved interacting residues leading to conformational change.

Adenosine is an endogenous autacoid that regulates cellular physiology via adenosine $A_{1}, A_{2 A}, A_{2 B}$, and $A_{3}$ receptors. These receptors are expressed in several cells and tissues throughout the body and play a crucial role in regulating the pathophysiology of the human body, suggesting a potential drug target. Of different adenosine receptor subtypes, $\mathrm{A}_{2 \mathrm{~A}} \mathrm{R}$ is the main receptor subtype in the striatum colocalized with dopamine $D_{2}$ receptor and it modulates motor function $[27,28]$. Activation of $A_{2 A} R$ decreases the binding affinity of $D_{2} R$ for agonists, implying $\mathrm{A}_{2 \mathrm{~A}} \mathrm{R}$ antagonists as novel therapeutics for Parkinson's disease [29]. At the synapse, $\mathrm{A}_{2 \mathrm{~A}} \mathrm{R}$ facilitates glutamate release and potentiates NMDA receptor effects. It also stimulates glutamate release in astrocytes by inhibiting glutamate transporter-1 (GLT-1), and the level of $\mathrm{A}_{2 \mathrm{~A}}$ Rs in neurons and glia is significantly high in depression and Schizophrenia [30]. Hence, $\mathrm{A}_{2 \mathrm{~A}} \mathrm{Rs}$ antagonists are effective as antidepressants and anti-anxiety agents. Here, dieckol and PFF-A showed an antagonist effect at $\mathrm{hA} \mathrm{A}_{\mathrm{A}} \mathrm{R}$ with $\mathrm{IC}_{50}$ values of $87.18 \pm 2.63$ and $<50 \mu \mathrm{M}$, respectively. Furthermore, molecular docking simulation showed that dieckol and phlorofucofuroeckol-A strongly interact with the Phe168 residue, which is known as one of the important residues for ligand binding, via pi-pi interaction [31]. Structurally, dieckol and PFF-A are powerful radical scavengers [32] and as such, dieckol, in a recent study [33], protected dopaminergic neuronal cells by preventing $\alpha$-synuclein aggregation via antioxidant mechanism. In a previous study [34], dieckol suppressed LPS-induced excessive microglial activation and protected neuronal cells by downregulating extracellular signal-regulated kinases, protein kinase B (PKB/Akt), and nicotinamide adenine dinucleotide phosphate hydrogen (NADPH) oxidase-mediated 
pathways. Likewise, PFF-A inhibited glutamate-induced apoptotic PC12 cell death in a caspase-dependent manner [35].

Similarly, at $\alpha_{2 C}$ AR, PFF-A showed a strong agonist effect and formed an H-bond with the Asp131 of $\alpha_{2 C} \mathrm{AR}$, which is the conserved active site residue. Adrenergic receptors are targets for epinephrine and norepinephrine and are involved in maintaining homeostasis. Among several types of adrenergic receptors, highly expressed $\alpha_{2}$ adrenoreceptors in astrocytes, and in glutamatergic and GABAergic neurons act by increasing intracellular $\mathrm{Ca}^{2+}$ levels [36]. The $\alpha_{2 C} A R$ subtype mediates cold-induced vasoconstriction, inhibits dopamine release in basal ganglia [37], and serotonin in the mouse hippocampus [38]. Therefore, $\alpha_{2 C} \mathrm{AR}$ selective ligands have a therapeutic role in neuropsychiatric disorders [38] and $\alpha_{2 C} \mathrm{AR}$ agonists are implicated in the treatment of neuropathic pain [39-41].

Serotonin (5-hydroxytryptamine, 5-HT) is a monoamine neurotransmitter that plays a crucial role in physiological functions, and of a total of 14 subtypes of 5-HT receptors, the $5-\mathrm{HT}_{1 \mathrm{~A}}$ receptor is a prominent target for the treatment of various neuropsychiatric and neurological disorders, prominently depression [42]. In the functional assay, dieckol and PFFA showed a good antagonist effect at $5-\mathrm{HT}_{1 \mathrm{~A}} \mathrm{R}$. Furthermore, they interacted with conserved aspartate residue (Asp116) of 5- $\mathrm{HT}_{1 \mathrm{~A}} \mathrm{R}$ via $\mathrm{H}$-bond and pi-anion binding, respectively.

Vasopressin is an antidiuretic hormone that plays a vital role in the central nervous system (CNS) and peripheral nervous system (PNS). The vasopressin receptor is one of the promising targets for CNS drugs, and vasopressin antagonists represent a novel approach for the treatment of stress, mood, and behavioral disorders [43]. Likewise, as a peripheral role, $\mathrm{V}_{1 \mathrm{~A}} \mathrm{R}$ is responsible for vasoconstriction, myocardial contractility, platelet aggregation, and uterine contraction [44]. Similarly, in a recent study [45], upregulated vasopressin 1 receptor $\left(V_{1} R\right)$ expression in hepatocytes of ischemia-reperfusion injury mouse model was identified and the $\mathrm{V}_{1} \mathrm{R} / \mathrm{Wnt} / \beta$-catenin/FoxO3a/Akt pathway was highlighted as vital for hepatoprotection.

Cannabinoid $\mathrm{CB}_{1}$ receptors are among the most abundant GPCRs in the brain and they modulate $\mathrm{CNS}$ activity [46]. Cannabinoid $\mathrm{CB}_{1}$ receptor agonist activation of the $\mathrm{CB}_{1}$ receptor leads to decreased levels in cellular cAMP via inhibition of adenylyl cyclase. Moreover, $\mathrm{CB}_{1}$ activation inhibits voltage-gated $\mathrm{Ca}^{2+}$ channels and activates $\mathrm{K}^{+}$channels, and these overall intracellular signaling activities reduce cellular excitability [47]. Likewise, studies also indicate high expression levels of $\mathrm{CB}_{1} \mathrm{R}$ in various types of cancer $[48,49]$. Interestingly, a new study demonstrated a higher orexigenic effect of the $C_{1} R$ agonist AM11101 than tetrahydrocannabinol [50]. This shows that $\mathrm{CB}_{1} \mathrm{R}$ agonists could be used as an appetite stimulant in underweight patients. In the present study, only PFF-A showed a promising agonist effect at $\mathrm{CB}_{1} \mathrm{R}$ with an $\mathrm{EC}_{50}$ of $13.42 \pm 2.03 \mu \mathrm{M}$. Several reports on PFF-A show neuroprotective effects mainly via antioxidant mechanisms [14,35,51]. Likewise, a recent study suggested the ATF3-mediated pathway as a possible mechanism of PFFA-induced apoptosis in human colorectal cancer cells [52]. However, it remains unclear whether the neuroprotective and anticancer effect of PFF-A is via $C_{1} R$ agonist activity.

The human $\mathrm{CB}_{1}$ receptor is an important therapeutic target for obesity and obsessive disorders and the mechanism of its transition state (either active or inactive) is vital for understanding the regulatory action of the receptor [53]. A salt bridge between conserved Asp-Arg-Tyr (DRY) motif in the C-terminal region of transmembrane 3 (TM3) and transmembrane 6 (TM6) characterizes the active or inactive conformation of the rhodopsin-like GPCRs [54]. In an inactive conformation of $\mathrm{CB}_{1} \mathrm{R}$, TM6 packs against TM3 and transmembrane 5 (TM5) and G protein-interacting residues-Phe200 (helix III) and Trp356 (helix VI) are obstructed [55]. The reference inverse agonist (taranabant) is bound to the inactive state crystal structure by forming an $\mathrm{H}$-bond interaction between the $\mathrm{NH}$ of taranabant and the hydroxyl of Ser383 and the $-\mathrm{CF}_{3}$ group with Ser173, Phe189, and Lys192. This result corroborates the findings of a previous study [56] which concluded that a strong $\mathrm{H}$-bond between the - $\mathrm{NH}$ group of taranabant and the hydroxyl of Ser383 was vital for superior affinity to $\mathrm{CB}_{1} \mathrm{R}$. Likewise, the agonist CP55940 formed $\pi-\pi$ interactions with Phe170 and Phe268, and two H-bond interactions with Ser173 and Ser383 in a similar 
fashion, as reported earlier [56]. PFFA also formed a stable pi-pi interaction with Phe268 and an H-bond interaction with Ser173 of the active state crystal structure (6kqi), which could explain the agonist potency of PFFA in vitro.

Among the tested protein targets, $\mathrm{CB}_{1} \mathrm{R}$, GLP-1, and GPR40 are obesity/T2DM related GPCRs and in the functional assays, PFF-A showed a good agonist effect at $C_{1} R$, while both the dieckol and PFF-A showed an antagonist effect at the GLP-1 receptor. Their effect at GPR40 was mild agonist. A gut-derived incretin hormone GLP-1 stimulates insulin and suppresses glucagon secretion, inhibits gastric emptying, and reduces appetite and food intake. In a previous study, intracerebroventricular injection of exendin (9-39), a specific GLP-1 antagonist, blocked the inhibitory effect of GLP-1 on food intake [57]. Hence, GLP-1 agonists represent a new class of antidiabetic agents [58]. In a recent study on the anti-diabetic effect in the zebrafish model [59], dieckol treatment reduced liver glucose6-phosphate and phosphoenolpyruvate carboxykinase, and enhanced glucose transport and insulin sensitivity via protein kinase B (Akt) phosphorylation. It is of note that dieckol and PFF-A showed a good antagonist effect at GLP-1. Thus, the in vivo effects of these phlorotannins in GLP-1-mediated signaling are urgent.

In conclusion, the present study characterizes the receptors $h A_{2 A} R, h \alpha_{2 C} A R, h \delta$ $\mathrm{OP}, \mathrm{CB}_{1} \mathrm{R}, \mathrm{GLP}-1, \mathrm{hV}_{1 \mathrm{~A}} \mathrm{R}$, and $\mathrm{h} 5-\mathrm{HT}_{1 \mathrm{~A}} \mathrm{R}$ as prime protein targets of dieckol and PFF-A. Moreover, the binding mechanism of test ligands with the target proteins strengthens the study and warrants further in vivo studies.

\section{Materials and Methods}

\subsection{Chemicals and Reagents}

A transfected Chinese hamster ovary (CHO), Hela, a murine interleukin-3 dependent pro-B (Ba/F3), PC12, and rat basophil leukemia cell lines were obtained from Eurofins Scientific (Eurofins-Cerep, Le Bois I'Eveque, France). Buffers-Dulbecco's modified Eagle medium (DMEM) buffer, 4-(2-hydroxyethyl)-1-piperazineethanesulfonic acid (HEPES) buffer, and Hank's balanced salt solution (HBSS) buffer-were purchased from Invitrogen (Carlsbad, CA, USA). The reference agonists: $5^{\prime}-N$-ethylcarboxamidoadenosine (NECA), epinephrine bitartrate, epinephrine, DPDPE, CP 55940, linoleic acid, GLP-1(7-37, arginine vasopressin (AVP), and serotonin, and antagonists: ZM 241385, RX-821002, rauwolscine, naltriben mesylate, AM 281, exendin-3(9-39), [d( $\left.\mathrm{CH}_{2}\right)_{5}{ }^{1}$, Tyr (Me) $)_{2}$-AVP, (S)-WAY-100635, and GR55562) were obtained from Sigma-Aldrich (St. Louis, MO, USA). All other chemicals and reagents purchased from Merck and Fluka were of the highest available grade unless otherwise stated.

\subsection{Isolation of Phlorotannins}

Phlorotannins-dieckol and PFF-A were isolated from the ethyl acetate fraction of $E$. stolonifera ethanolic extract, as described previously [11,22].

\subsection{In Silico Prediction of Targets}

To predict potential protein targets for the phlorotannins, a proteocheminformatics modeling (PCM) in silico target prediction method was employed, as described recently [60]. For full information on the model, readers are further directed to a previous report [61].

\subsection{Functional GPCR Assay}

The functional assay using transfected cells expressing human cloned receptors, PC12 cells for adenosine $\mathrm{A}_{2 \mathrm{~A}}$ receptor, rat basophil leukemia cells for human adrenergic alpha2A receptor, human delta opioid ( $\delta$-OP) receptor, $\mathrm{CHO}$ cells for adrenergic alpha $2 \mathrm{C}$ receptor, human cannabinoid $\mathrm{CB}_{1}$, and vasopressin $\left(\mathrm{V}_{1 \mathrm{~A}} \mathrm{R}\right)$, human embryonic kidney 293 (HEK293) cells for free fatty acid receptor 1 (FFA ${ }_{1} R$ or GPR40), $\beta T C 6$ cells for the glucagonlike peptide-1 receptor (GLP-1), Ba/F3 cells for serotonin (5- $\left.\mathrm{HT}_{1 \mathrm{~A}}\right)$, and Hela for $5-\mathrm{HT}_{1 \mathrm{~B}}$ receptors were carried out at Eurofins laboratory (Eurofins-Cerep, Le Bois I'Eveque, France). 
The in-house assay protocol and experimental conditions are reported in our previous reports $[15,22,62]$. The functional effect of dieckol and PFF-A was characterized based on their modulation effect on cytosolic $\mathrm{Ca}^{2+}$ ion mobilization using a fluorimetric detection method or by measuring their effect on cAMP modulation using homogeneous timeresolved fluorescence (HTRF) detection.

\subsection{Measurement of cAMP Level}

Functional activity of phlorotannins over $h A_{2 A} R, h \alpha_{2 C} A R, h C B_{1} R, G L P-1 R$, and h5$\mathrm{HT}_{1 \mathrm{~B}} \mathrm{R}$ was determined by measuring their effects on cAMP production by the HTRF detection method using transected cells expressing human cloned receptors.

\subsubsection{Functional Activity over $\mathrm{h} \mathrm{A}_{2 \mathrm{~A}} \mathrm{R}$}

In brief, the PC12 cells were suspended in HBSS buffer (Invitrogen) complemented with $20 \mathrm{mM}$ HEPES (pH 7.4), 0.2 U/mL ADA, and $100 \mu \mathrm{M}$ rolipram, then distributed in microplates at a density of $2.10^{3}$ cells / well and preincubated for $5 \mathrm{~min}$ at room temperature (RT) in the presence of HBSS (basal control), the test compound, or the reference agonist or antagonist. For stimulated control measurement, separate assay wells contained $3 \mu \mathrm{M}$ NECA. Following $10 \mathrm{~min}$ incubation at RT, the cells were lysed and the fluorescence acceptor (D2-labeled cAMP) and fluorescence donor (anti-cAMP antibody labeled with europium cryptate) were added. After $60 \mathrm{~min}$ at RT, the fluorescence transfer was measured at $\lambda \mathrm{ex}=337 \mathrm{~nm}$ and $\lambda \mathrm{em}=620$ and $665 \mathrm{~nm}$ using an EnVision microplate reader EnSpire (PerkinElmer, Waltham, MA, USA). The cAMP concentration was determined by dividing the signal measured at $665 \mathrm{~nm}$ by that measured at $620 \mathrm{~nm}$ (ratio). Agonist result was expressed as a percent of the control response to $3 \mu \mathrm{M}$ NECA while the antagonist effect as percent inhibition of the control response to $100 \mathrm{nM}$ NECA. The standard reference agonist was NECA and the antagonist was ZM 241385, which were tested in each experiment at several concentrations to generate a concentration-response curve from which their $\mathrm{EC}_{50}$ and $\mathrm{IC}_{50}$ values were calculated.

\subsubsection{Functional Activity over $h \alpha_{2 C} A R$}

Briefly, the transfected CHO cells suspended in HBSS buffer (Invitrogen) complemented with $20 \mathrm{mM}$ HEPES (pH 7.4) and $500 \mu \mathrm{M}$ IBMX were distributed in microplates at a density of $10^{4}$ cells/well in the presence of either of the following: For agonist assay-HBSS (basal control), epinephrine $1 \mu \mathrm{M}$ (stimulated control) or various concentrations (EC $\mathrm{EC}_{50}$ determination), or the test compounds. For antagonist assay-HBSS (stimulated controls), rauwolscine $10 \mu \mathrm{M}$ (basal control) or various concentrations ( $\mathrm{IC}_{50}$ determination), or the test compounds. The reference agonist epinephrine and the adenylyl cyclase activator $\mathrm{NKH}$ 477 were added at respective final concentrations of $100 \mathrm{nM}$ and $5 \mu \mathrm{M}$. For basal control measurements, epinephrine was omitted from the wells containing $3 \mu \mathrm{M}$ rauwolscine. After $10 \mathrm{~min}$ at $37^{\circ} \mathrm{C}$, the cells were lysed and the fluorescence acceptor (D2-labeled cAMP) and fluorescence donor (anti-cAMP antibody labeled with europium cryptate) were added. After $60 \mathrm{~min}$ at RT, the fluorescence transfer was measured at $\lambda \mathrm{ex}=337 \mathrm{~nm}$ and $\lambda \mathrm{em}=620$ and $665 \mathrm{~nm}$ using a microplate reader (Envision, Perkin Elmer). The concentration of cAMP was determined by dividing the measured signal at $665 \mathrm{~nm}$ by that measured at $620 \mathrm{~nm}$ (ratio). The agonist result are shown as a percent of the control response to $1 \mu \mathrm{M}$ epinephrine and the antagonist result are expressed as a percent inhibition of the control response to $30 \mathrm{nM}$ epinephrine. Epinephrine and rauwolscine were the standard reference drugs used in each experiment at different concentrations.

\subsubsection{Functional Activity over $h \mathrm{hB}_{1} \mathrm{R}$}

The transfected CHO cells were suspended in HBSS buffer (Invitrogen) complemented with $20 \mathrm{mM}$ HEPES ( $\mathrm{pH}$ 7.4). Then, the cells were distributed in microplates at a density of $5.10^{3}$ cells/well in the presence of either of the following: For agonist assay-HBSS (basal control), $30 \mathrm{nM} \mathrm{CP} 55940$ (stimulated control) or various concentrations (EC 50 
determination), or the test compounds. For antagonist assay-HBSS (stimulated controls), $10 \mu \mathrm{M}$ AM 281 (basal control) or various concentrations for $\mathrm{IC}_{50}$ determination, or the test compounds. Thereafter, the reference agonist CP 55940 and the adenylyl cyclase activator forskolin were added at respective final concentrations of $1 \mathrm{nM}$ and $25 \mu \mathrm{M}$. For basal control measurements, CP 55940 was excluded from the wells containing $10 \mu \mathrm{M}$ AM 281. After $30 \mathrm{~min}$ of incubation at $37^{\circ} \mathrm{C}$, the cells were lysed and the fluorescence acceptor (D2-labeled cAMP) and fluorescence donor (anti-cAMP antibody labeled with europium cryptate) were added. The fluorescence transfer was measured at $\lambda \mathrm{ex}=337 \mathrm{~nm}$ and $\lambda \mathrm{em}=620$ and $665 \mathrm{~nm}$ using an Envision microplate reader (PerkinElmer, Waltham, MA, USA) after $60 \mathrm{~min}$ at RT. The agonist results are expressed as a percent of the control response to $10 \mathrm{nM} \mathrm{CP} 55940$ and the antagonist results are expressed as percent inhibition of the control response to $1 \mathrm{nM} \mathrm{CP} \mathrm{55940.} \mathrm{CP} 55940$ and AM 281 were standard reference drugs that were tested in each experiment.

\subsubsection{Functional Activity over GLP-1R}

The HBSS buffer (Invitrogen) complemented with 20 mM HEPES (pH 7.4) and $500 \mu \mathrm{M}$ IBMX was used to suspend and distribute the $\beta$ TC 6 cells at a density of $1.5 \times 10^{4}$ cells/well. The plate was then incubated for $10 \mathrm{~min}$ at RT in the presence of HBSS (basal and stimulated control), the test compound, or the reference agonist and antagonist. In the agonist assay,

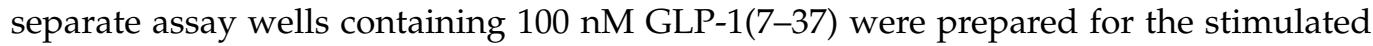
control measurement, while in the antagonist assay, the reference agonist GLP-1(7-37) was added at a final concentration of $0.3 \mathrm{nM}$, and separate assay wells contained HBSS for basal control measurements. Following incubation, the cells were lysed and the fluorescence acceptor (D2-labeled cAMP) and fluorescence donor (anti-cAMP antibody labeled with europium cryptate) were added. After $60 \mathrm{~min}$ at room temperature, the fluorescence transfer was measured at $\lambda e x=337 \mathrm{~nm}$ and $\lambda \mathrm{em}=620 \mathrm{~nm}$ and $665 \mathrm{~nm}$ using an Envision microplate reader (PerkinElmer, Waltham, MA, USA). The results are expressed as either a percent of the control response to $100 \mathrm{nM} \mathrm{GLP-1(7-37)} \mathrm{or} \mathrm{a} \mathrm{percent} \mathrm{inhibition} \mathrm{of} \mathrm{the} \mathrm{control}$ response to $0.3 \mathrm{nM}$ GLP-1(7-37). The standard reference agonist was GLP-1(7-37) and the antagonist was exendin-3(9-39).

\subsubsection{Functional Activity over $5-\mathrm{HT}_{1 \mathrm{~B}} \mathrm{R}$}

Concisely, a plasmid containing the GPCR gene of interest (5- $\left.\mathrm{HT}_{1 \mathrm{~B}}\right)$ was transfected into Hela cells. The resulting stable transfectants were suspended in HBSS buffer (Invitrogen, Carlsbad, CA, USA) containing $20 \mathrm{mM}$ HEPES (pH 7.4), $400 \mathrm{mM} \mathrm{NaCl}, 1 \mathrm{mg} / \mathrm{mL}$ glucose, and $500 \mu \mathrm{M}$ IBMX and distributed in microplates at a density of $2 \times 10^{4}$ cells/well. The plates were then incubated for $20 \mathrm{~min}$ at RT in the presence of either of the following: HBSS and $0.1 \%$ BSA (basal control), serotonin at $10 \mu \mathrm{M}$ (stimulated control) or various concentrations for $\mathrm{EC}_{50}$ determination, or the test phlorotannins. Thereafter, the adenylyl cyclase activator NKH $477(5 \mu \mathrm{M})$ was added and the plates were incubated at $37^{\circ} \mathrm{C}$ for $20 \mathrm{~min}$. Then, the cells were lysed and a fluorescence acceptor (D2-labeled cAMP) and fluorescence donor (anti-cAMP antibody with europium cryptate) were added following $60 \mathrm{~min}$ incubation at RT. After incubation, the fluorescence transfer was measured using an Envision microplate reader (PerkinElmer, Waltham, MA, USA) and the results are expressed as a percentage of the control response to $10 \mu \mathrm{M}$ serotonin for the agonist effect and as percent inhibition of the control response to $100 \mathrm{nM}$ serotonin.

\subsection{Measurement of Intracellular $\left[\mathrm{Ca}^{2+}\right]$ Level}

Functional activity of phlorotannins over human adrenergic $\alpha 2 \mathrm{~A}\left(\mathrm{~h} \alpha_{2 \mathrm{~A}}\right)$, human $\delta$ opioid (h--OP), free fatty acid receptor $1\left(\mathrm{FFA}_{1} \mathrm{R} / \mathrm{GPR} 40\right)$, human vasopressin $1 \mathrm{~A}\left(\mathrm{hV} \mathrm{V}_{1 \mathrm{~A}}\right)$, and human serotonin $1 \mathrm{~A}\left(\mathrm{~h} 5-\mathrm{HT}_{1 \mathrm{~A}}\right)$ receptors was assessed by measuring their effect on cytosolic $\mathrm{Ca}^{2+}$ ion mobilization at the transected cells expressing human cloned receptors using a fluorimetric detection method. 


\subsubsection{Functional Activity over $h \alpha_{2 \mathrm{~A}} \mathrm{AR}$}

The rat basophil leukemia cells were distributed in microplates at a density of $1.1 \times 10^{4}$ cells/well after suspending in a HBSS buffer (Invitrogen) containing 20 mM HEPES. Then, the fluorescent probe (Fluo8, AAT Bioquest) mixed with probenecid in HBSS buffer (Invitrogen) complemented with $20 \mathrm{mM}$ Hepes (Millipore) ( $\mathrm{pH}$ 7.4) was added into each well incubated for $60 \mathrm{~min}$ at $30^{\circ} \mathrm{C}$. Thereafter, the assay plates were positioned in a microplate reader (FlipR Tetra, Molecular Device) and we added test compounds, reference agonist/antagonist or HBSS buffer (basal control). Change in fluorescence intensity which varies proportionally to the free cytosolic $\mathrm{Ca}^{2+}$ ion concentration was measured. For stimulated control measurements, separate assay wells containing $0.1 \mu \mathrm{M}$ epinephrine bitartrate were prepared. The agonist effect was calculated as a \% of control response to epinephrine bitartrate at $0.1 \mu \mathrm{M}$. Similarly, for the antagonist effect, \% inhibition of the control response to epinephrine bitartrate at $3 \mathrm{nM}$ was evaluated. Epinephrine bitartrate and RX-821002 were used as reference agonists and antagonists, respectively.

\subsubsection{Functional Activity over $\mathrm{h} \delta$-OPR}

At first, rat basophil leukemia cells were suspended in HBSS buffer (Invitrogen) complemented with $20 \mathrm{mM}$ HEPES, and distributed in microplates at a density of $2.768 \times 10^{4}$ cells/well. Thereafter, a mixture of fluorescent probe (Fluo8, AAT Bioquest) and probenecid in HBSS buffer (Invitrogen) complemented with $20 \mathrm{mM}$ Hepes (Millipore) (pH 7.4) was added and plates were incubated for $60 \mathrm{~min}$ at $30^{\circ} \mathrm{C}$. Then, the assay plates were positioned in a FlipR Tetra microplate reader (Molecular Device, San Jose, CA, USA) for the addition of the test compound, reference agonist/antagonist, or HBSS buffer (basal control). Change in fluorescence intensity that varies proportionally to the free cytosolic $\mathrm{Ca}^{2+}$ ion concentration was measured.

For stimulated control measurements, $1 \mu \mathrm{M}$ DPDPE was added in separate assay wells. The results are expressed as a percent of the control response to DPDPE at $1 \mu \mathrm{M}$ or a percent inhibition of the control response to DPDPE at $25 \mathrm{nM}$. The standard reference agonist and antagonist were DPDPE and naltriben mesylate, respectively.

\subsubsection{Functional Activity over $\mathrm{FFA}_{1} \mathrm{R} / \mathrm{GPR} 40$}

In general, transfected HEK-293 cells suspended in DMEM buffer (Invitrogen) containing $1 \%$ FCSd were distributed in microplates at a density of $2.10^{4}$ cells/well. Then, the mixture of fluorescent probe (Fluo4 Direct, Invitrogen) and probenecid in HBSS buffer (Invitrogen) complemented with $20 \mathrm{mM}$ Hepes (Invitrogen) ( $\mathrm{pH} 7.4$ ) was added into each well and incubated for $60 \mathrm{~min}$ at $37^{\circ} \mathrm{C}$, followed by $15 \mathrm{~min}$ incubation at $22^{\circ} \mathrm{C}$. Thereafter, the assay plates were positioned in a CellLux microplate reader (PerkinElmer, Waltham, MA, USA) which was used for the addition of the following: For agonist assay-test compound, reference agonist, or HBSS buffer (basal control). Linoleic acid at $100 \mu \mathrm{M}$ was added in separate assay wells for stimulated control measurement. For antagonist assay-test compound or HBSS buffer (basal and stimulated control), then, 5 min later, $20 \mu \mathrm{M}$ linoleic acid. Agonist results are expressed as a percent of the control response to $100 \mu \mathrm{M}$ linoleic acid while antagonist results are expressed as percent inhibition of the control response to $20 \mu \mathrm{M}$ linoleic acid.

\subsubsection{Functional Activity over $h V_{1 \mathrm{~A}} \mathrm{R}$}

Briefly, $\mathrm{CHO}-\mathrm{V}_{1 \mathrm{~A}} \mathrm{R}$ cells were separately suspended in DMEM buffer (Invitrogen, Carlsbad, CA, USA) complemented with $0.1 \%$ FCSd and distributed into microplates $\left(4.5 \times 10^{4}\right.$ cells / well). Then, fluorescent probe (Fluo4, Invitrogen) mixed with probenecid in HBSS buffer (Invitrogen, Carlsbad, CA, USA) supplemented with 20 mM HEPES, pH 7.4 (Invitrogen) was added to each well, allowing to equilibrate with the cells for $60 \mathrm{~min}$ at $37^{\circ} \mathrm{C}$, then $15 \mathrm{~min}$ at $22{ }^{\circ} \mathrm{C}$. Thereafter, the assay plates were positioned in a CellLux microplate reader (PerkinElmer, Waltham, MA, USA) and dieckol and PFF-A $(12.5,25,50$, 100 , and/or $150 \mu \mathrm{M}$ ), reference agonist, or HBSS buffer (basal control) was added. For 
stimulated control measurements, AVP at $1 \mu \mathrm{M}$ was added in separate assay wells. The agonist effect on $V_{1 A} R$ was calculated as a \% of control response to $1 \mu \mathrm{M}$ AVP. Similarly, for the antagonist effect, \% inhibition of the control response to $10 \mathrm{nM}$ AVP was evaluated. AVP and $\left[\mathrm{d}\left(\mathrm{CH}_{2}\right)_{5}{ }^{1}\right.$, Tyr $\left.(\mathrm{Me})_{2}\right]$-AVP were used as reference agonist and antagonist, respectively.

\subsubsection{Functional Activity over h5- $\mathrm{HT}_{1 \mathrm{~A}} \mathrm{R}$}

In brief, Ba/F3-5HT $1 \mathrm{~A}$ R cells were first suspended in HBSS buffer (Invitrogen, Carlsbad, CA, USA) complemented with 20 mM HEPES buffer (pH 7.4). Then, the cells were distributed into microplates at a density of $1 \times 10^{6}$ cells/well. Subsequently, fluorescent probe (Fluo8, AAT Bioquest) mixed with probenecid in HBSS buffer (Invitrogen, Carlsbad, CA, USA) supplemented with 20 mM HEPES (Invitrogen) (pH 7.4) was added to each well, and the plates were incubated for $60 \mathrm{~min}$ at $37^{\circ} \mathrm{C}$. Thereafter, plates were fixed in a FlipR Tetra microplate reader (Molecular Device, San Jose, CA, USA) and dieckol and PFF-A (12.5, 25, 50, 100 and/or $150 \mu \mathrm{M})$, reference agonist, or HBSS buffer (basal control) was added. Fluorescence intensity was measured which varied in proportion to the free cytosolic $\mathrm{Ca}^{2+}$ ion concentration. Agonist effect on $5-\mathrm{HT}_{1 \mathrm{~A}} \mathrm{R}$ was calculated as a \% of control response to $2.5 \mu \mathrm{M}$ serotonin. Similarly, the percentage inhibition of the control response to $30 \mathrm{nM}$ serotonin was calculated for the antagonist effect. Serotonin and (S)-WAY-100635 were used as reference agonists and antagonists, respectively.

\subsection{Homology Modeling and Molecular Docking}

The primary sequence of the human $5-\mathrm{HT}_{1 \mathrm{~A}} \mathrm{R}$ and human $\mathrm{V}_{1 \mathrm{~A}} \mathrm{R}$ was obtained from UniProt (ID: P08908 and P37288, respectively). Based on the SWISS-MODEL, the 5-HT $1 \mathrm{~B}$ receptor (PDB: 5V54) was selected as a template for homology modeling of human $5-\mathrm{HT}_{1 \mathrm{~A}}$ because it showed a good sequence similarity (0.42), sequence identity (42.97), and quaternary structure quality estimate (QSQE) (0.32) to this receptor. Similarly, $\mu$-opioid receptor (PDB: 4DKL) was selected as a template for homology modeling of human $\mathrm{V}_{1 \mathrm{~A}} \mathrm{R}$, because it showed a good sequence similarity (0.32), sequence identity (24.54), and QSQE (0.19) to this receptor. The constructed model was refined using the ModRefiner server. Automated docking simulations were carried out with the AutoDock 4.2. program [63]. The structures of dieckol and PFF-A were generated and converted into 3D structures using Marvin Sketch (v17,1,30, ChemAxon, Budapest, Hungary). Structures of dieckol and PFF-A were energy-minimized using a molecular mechanics 2 (MM2) force field. X-ray crystallographic structures of GPCRs were obtained from the RCSB protein data bank (PDB) with respec-

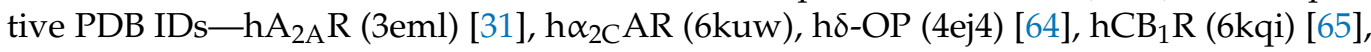
and hGLP-1 [66]. The structures of reported agonists $\left(5^{\prime}-N\right.$-ethylcarboxamidoadenosine (NECA), epinephrine, DPI-287, CP 55940, PF-06882961, AVP, and serotonin, and antagonists (ZM241385, RS-79948, naltrindole, taranabant, NNC0640, SR49059, and WAY 100635) were downloaded from PubChem or PDB. For each ligand-protein complex, 10 docking poses were generated using the same grid parameters (size and center) and docking parameters (genetic algorithm and run options). The pose for the lowest binding energy was chosen for the final docking result. When the root-mean-square deviation (RMSD) value between our docking result and the original crystallographic structures of the protein was less than $0.15 \mathrm{~nm}$, we considered our docking protocol to be valid and performed the simulation. Results were analyzed and visualized using Discovery Studio (v17.2, Accelrys, San Diego, CA, USA).

Supplementary Materials: The following are available online at https:/ / www.mdpi.com/article/10 $.3390 / \mathrm{md19060326/s1}$, Table S1: Hydrogen bonding interaction residues between ligand-GPCRs $\left(\mathrm{hA} \mathrm{A}_{2 \mathrm{~A}} \mathrm{R}, \mathrm{h} \alpha_{2 \mathrm{C}} \mathrm{AR}\right.$, and $\left.\mathrm{hDOP}\right)$, Table S2: Hydrophobic and electrostatic interaction residues between ligand-GPCRs ( $h A_{2 A} R, h \alpha_{2 C} A R$, and hDOP), Table S3: Hydrogen, halogen, or electrostatic bonding interaction residues between ligand-GPCRs ( $\mathrm{hCB}_{1} \mathrm{R}$ and hGLP-1), Table S4: Hydrophobic interaction residues between ligand-GPCRs ( $\mathrm{hCB}_{1} \mathrm{R}$ and hGLP-1), Table S5: Hydrogen bonding interaction residues between ligand-GPCRs $\left(\mathrm{hV}_{1 \mathrm{~A}} \mathrm{R}\right.$ and $\left.\mathrm{h} 5-\mathrm{HT}_{1 \mathrm{~A}} \mathrm{R}\right)$, and Table S6: Hydrophobic and electrostatic interaction residues between ligand-GPCRs $\left(h V_{1 \mathrm{~A}} \mathrm{R}\right.$ and $\left.\mathrm{h} 5-\mathrm{HT}_{1 \mathrm{~A}} \mathrm{R}\right)$. 
Author Contributions: Bioassays and original draft preparation, P.P.; in silico assays and writing, S.H.S.; in silico assay, S.E.P.; writing—edit, J.H.R.; writing-review and supervision, H.A.J. and J.S.C. All authors have read and agreed to the published version of the manuscript.

Funding: The Basic Science Research Program supported this research through the National Research Foundation of Korea (NRF) funded by the Ministry of Science (2012R1A6A1028677).

Institutional Review Board Statement: Not applicable.

Acknowledgments: We would like to thank Fazlin Mohd Fauzi, Department of Pharmacology and Chemistry, Faculty of Pharmacy, Universiti Teknologi MARA, Selangor Branch, Puncak Alam Campus, 42300 Bandar Puncak Alam, Selangor, Malaysia, for proteocheminformatics modeling.

Conflicts of Interest: The authors declare no conflict of interest.

\section{References}

1. Iliopoulos-Tsoutsouvas, C.; Kulkarni, R.N.; Makriyannis, A.; Nikas, S.P. Fluorescent probes for G-protein-coupled receptor drug discovery. Expert Opin. Drug Discov. 2018, 13, 933-947. [CrossRef]

2. Schlyer, S.; Horuk, R. I want a new drug: G-protein-coupled receptors in drug development. Drug Discov. Today 2006, 11, 481-493. [CrossRef] [PubMed]

3. Kim, H.R.; Xu, J.; Maeda, S.; Duc, N.M.; Ahn, D.; Du, Y.; Chung, K.Y. Structural mechanism underlying primary and secondary coupling between GPCRs and the Gi/o family. Nat. Commun. 2020, 11, 3160. [CrossRef]

4. Wang, X.; Wang, Z.-Y.; Zheng, J.-H.; Li, S. TCM network pharmacology: A new trend towards combining computational, experimental and clinical approaches. Chin. J. Nat. Med. 2021, 19, 1-11.

5. Do Valle, I.F.; Roweth, H.G.; Malloy, M.W.; Moco, S.; Barron, D.; Battinelli, E.; Loscalzo, J.; Barabási, A.-L. Network medicine framework shows that proximity of polyphenol targets and disease proteins predicts therapeutic effects of polyphenols. Nat. Food 2021, 2, 143-155. [CrossRef]

6. Nakamura, T.; Nagayama, K.; Uchida, K.; Tanaka, R. Antioxidant activity of phlorotannins isolated from the brown alga Eisenia bicyclis. Fish. Sci. 1996, 62, 923-926. [CrossRef]

7. Manandhar, B.; Wagle, A.; Seong, S.H.; Paudel, P.; Kim, H.-R.; Jung, H.A.; Choi, J.S. Phlorotannins with potential anti-tyrosinase and antioxidant activity isolated from the marine seaweed Ecklonia stolonifera. Antioxidants 2019, 8, 240. [CrossRef] [PubMed]

8. Eom, S.-H.; Kim, Y.-M.; Kim, S.-K. Antimicrobial effect of phlorotannins from marine brown algae. Food Chem. Toxicol. 2012, 50, 3251-3255. [CrossRef]

9. Lee, S.-H.; Jeon, Y.-J. Anti-diabetic effects of brown algae derived phlorotannins, marine polyphenols through diverse mechanisms. Fitoterapia 2013, 86, 129-136. [CrossRef] [PubMed]

10. Jung, H.A.; Oh, S.H.; Choi, J.S. Molecular docking studies of phlorotannins from Eisenia bicyclis with BACE1 inhibitory activity. Bioorg. Med. Chem. Lett. 2010, 20, 3211-3215. [CrossRef]

11. Yoon, N.Y.; Chung, H.Y.; Kim, H.R.; Choi, J.E. Acetyl- and butyrylcholinesterase inhibitory activities of sterols and phlorotannins from Ecklonia stolonifera. Fish. Sci. 2008, 74, 200. [CrossRef]

12. Seong, S.H.; Paudel, P.; Jung, H.A.; Choi, J.S. Identifying phlorofucofuroeckol-A as a dual inhibitor of amyloid- $\beta 25-35$ selfaggregation and insulin glycation: Elucidation of the molecular mechanism of action. Mar. Drugs 2019, 17, 600. [CrossRef]

13. Jung, H.A.; Jin, S.E.; Ahn, B.R.; Lee, C.M.; Choi, J.S. Anti-inflammatory activity of edible brown alga Eisenia bicyclis and its constituents fucosterol and phlorotannins in LPS-stimulated RAW264.7 macrophages. Food Chem. Toxicol. 2013, 59, 199-206. [CrossRef]

14. Ahn, B.R.; Moon, H.E.; Kim, H.R.; Jung, H.A.; Choi, J.S. Neuroprotective effect of edible brown alga Eisenia bicyclis on amyloid beta peptide-induced toxicity in PC12 cells. Arch. Pharm. Res. 2012, 35, 1989-1998. [CrossRef] [PubMed]

15. Paudel, P.; Seong, S.H.; Wu, S.; Park, S.; Jung, H.A.; Choi, J.S. Eckol as a potential therapeutic against neurodegenerative diseases targeting dopamine D3/D4 receptors. Mar. Drugs 2019, 17, 108. [CrossRef] [PubMed]

16. Jung, H.A.; Jung, H.J.; Jeong, H.Y.; Kwon, H.J.; Ali, M.Y.; Choi, J.S. Phlorotannins isolated from the edible brown alga Ecklonia stolonifera exert anti-adipogenic activity on 3T3-L1 adipocytes by downregulating C/EBP $\alpha$ and PPAR $\gamma$. Fitoterapia 2014, 92, 260-269. [CrossRef]

17. Lee, M.-S.; Shin, T.; Utsuki, T.; Choi, J.-S.; Byun, D.-S.; Kim, H.-R. Isolation and identification of phlorotannins from Ecklonia stolonifera with antioxidant and hepatoprotective properties in tacrine-treated HepG2 cells. J. Agri. Food Chem. 2012, 60, 5340-5349. [CrossRef] [PubMed]

18. Jung, H.A.; Roy, A.; Jung, J.H.; Choi, J.S. Evaluation of the inhibitory effects of eckol and dieckol isolated from edible brown alga Eisenia bicyclis on human monoamine oxidases A and B. Arch. Pharm. Res. 2017, 40, 480-491. [CrossRef] [PubMed]

19. Jung, H.A.; Hyun, S.K.; Kim, H.R.; Choi, J.S. Angiotensin-converting enzyme I inhibitory activity of phlorotannins from Ecklonia stolonifera. Fish. Sci. 2006, 72, 1292-1299. [CrossRef]

20. Kwon, H.-J.; Ryu, Y.B.; Kim, Y.-M.; Song, N.; Kim, C.Y.; Rho, M.-C.; Jeong, J.-H.; Cho, K.-O.; Lee, W.S.; Park, S.-J. In vitro antiviral activity of phlorotannins isolated from Ecklonia cava against porcine epidemic diarrhea coronavirus infection and hemagglutination. Bioorg. Med. Chem. 2013, 21, 4706-4713. [CrossRef] [PubMed] 
21. Kang, H.S.; Chung, H.Y.; Kim, J.Y.; Son, B.W.; Jung, H.A.; Choi, J.S. Inhibitory phlorotannins from the edible brown alga Ecklonia stolonifera on total reactive oxygen species (ROS) generation. Arch. Pharm. Res. 2004, 27, 194-198. [CrossRef]

22. Seong, S.H.; Paudel, P.; Choi, J.-W.; Ahn, D.H.; Nam, T.-J.; Jung, H.A.; Choi, J.S. Probing multi-target action of phlorotannins as new monoamine oxidase inhibitors and dopaminergic receptor modulators with the potential for treatment of neuronal disorders. Mar. Drugs 2019, 17, 377. [CrossRef] [PubMed]

23. Paricharak, S.; Cortés-Ciriano, I.; IJzerman, A.P.; Malliavin, T.E.; Bender, A. Proteochemometric modelling coupled to in silico target prediction: An integrated approach for the simultaneous prediction of polypharmacology and binding affinity/potency of small molecules. J. Cheminform. 2015, 7, 1-11. [CrossRef]

24. Burda, S.; Oleszek, W. Antioxidant and antiradical activities of flavonoids. J. Agric. Food Chem. 2001, 49, 2774-2779. [CrossRef]

25. Dugas, A.J., Jr.; Castañeda-Acosta, J.; Bonin, G.C.; Price, K.L.; Fischer, N.H.; Winston, G.W. Evaluation of the total peroxyl radical-scavenging capacity of flavonoids: Structure- activity relationships. J. Nat. Prod. 2000, 63, 327-331. [CrossRef]

26. Shibata, T.; Ishimaru, K.; Kawaguchi, S.; Yoshikawa, H.; Hama, Y. Antioxidant activities of phlorotannins isolated from Japanese Laminariaceae. In Nineteenth International Seaweed Symposium; Borowitzka, M.A., Critchley, A.T., Kraan, S., Peters, A., Sjøtun, K., Notoya, M., Eds.; Springer: Dordrecht, The Netherlands, 2007; Volume 2, pp. 255-261.

27. Borroto-Escuela, D.O.; Romero-Fernandez, W.; Tarakanov, A.O.; Gómez-Soler, M.; Corrales, F.; Marcellino, D.; Narvaez, M.; Frankowska, M.; Flajolet, M.; Heintz, N. Characterization of the A2AR-D2R interface: Focus on the role of the C-terminal tail and the transmembrane helices. Biochem. Biophys. Res. Commun. 2010, 402, 801-807. [CrossRef] [PubMed]

28. Fuxe, K.; Agnati, L.F.; Jacobsen, K.; Hillion, J.; Canals, M.; Torvinen, M.; Tinner-Staines, B.; Staines, W.; Rosin, D.; Terasmaa, A. Receptor heteromerization in adenosine A2A receptor signaling: Relevance for striatal function and Parkinson's disease. Neurology 2003, 61, S19-S23. [CrossRef] [PubMed]

29. Ferre, S.; Von Euler, G.; Johansson, B.; Fredholm, B.B.; Fuxe, K. Stimulation of high-affinity adenosine A2 receptors decreases the affinity of dopamine D2 receptors in rat striatal membranes. Proc. Natl. Acad. Sci. USA 1991, 88, 7238-7241. [CrossRef] [PubMed]

30. Yamada, K.; Kobayashi, M.; Kanda, T. Involvement of Adenosine A2A Receptors in Depression and Anxiety. Int. Rev. Neurobiol. 2014, 119, 373-393.

31. Jaakola, V.-P.; Griffith, M.T.; Hanson, M.A.; Cherezov, V.; Chien, E.Y.; Lane, J.R.; Ijzerman, A.P.; Stevens, R.C. The 2.6 angstrom crystal structure of a human A2A adenosine receptor bound to an antagonist. Science 2008, 322, 1211-1217. [CrossRef]

32. Kang, M.C.; Cha, S.H.; Wijesinghe, W.A.; Kang, S.M.; Lee, S.H.; Kim, E.A.; Song, C.B.; Jeon, Y.J. Protective effect of marine algae phlorotannins against AAPH-induced oxidative stress in zebrafish embryo. Food Chem. 2013, 138, 950-955. [CrossRef]

33. Cha, S.-H.; Heo, S.-J.; Jeon, Y.-J.; Park, S.M. Dieckol, an edible seaweed polyphenol, retards rotenone-induced neurotoxicity and $\alpha$-synuclein aggregation in human dopaminergic neuronal cells. RSC Adv. 2016, 6, 110040-110046. [CrossRef]

34. Cui, Y.; Park, J.Y.; Wu, J.; Lee, J.H.; Yang, Y.S.; Kang, M.S.; Jung, S.C.; Park, J.M.; Yoo, E.S.; Kim, S.H.; et al. Dieckol Attenuates Microglia-mediated Neuronal Cell Death via ERK, Akt and NADPH Oxidase-mediated Pathways. Korean J. Physiol. Pharmacol. 2015, 19, 219-228. [CrossRef] [PubMed]

35. Kim, J.-J.; Kang, Y.-J.; Shin, S.-A.; Bak, D.-H.; Lee, J.W.; Lee, K.B.; Yoo, Y.C.; Kim, D.-K.; Lee, B.H.; Kim, D.W. Phlorofucofuroeckol improves glutamate-induced neurotoxicity through modulation of oxidative stress-mediated mitochondrial dysfunction in PC12 cells. PLoS ONE 2016, 11, e0163433. [CrossRef] [PubMed]

36. Gaidin, S.G.; Turovskaya, M.V.; Mal'tseva, V.N.; Zinchenko, V.P.; Blinova, E.V.; Turovsky, E.A. A Complex Neuroprotective Effect of Alpha-2-Adrenergic Receptor Agonists in a Model of Cerebral Ischemia-Reoxygenation In Vitro. Biochemistry 2019, 13, 319-333. [CrossRef]

37. Bücheler, M.M.; Hadamek, K.; Hein, L. Two $\alpha 2$-adrenergic receptor subtypes, $\alpha 2 \mathrm{~A}$ and $\alpha 2 \mathrm{C}$, inhibit transmitter release in the brain of gene-targeted mice. Neuroscience 2002, 109, 819-826. [CrossRef]

38. Scheinin, M.; Sallinen, J.; Haapalinna, A. Evaluation of the $\alpha 2 \mathrm{C}$-adrenoceptor as a neuropsychiatric drug target: Studies in transgenic mouse models. Life Sci. 2001, 68, 2277-2285. [CrossRef]

39. Fairbanks, C.A.; Stone, L.S.; Kitto, K.F.; Nguyen, H.O.; Posthumus, I.J.; Wilcox, G.L. $\alpha 2$ C-Adrenergic receptors mediate spinal analgesia and adrenergic-opioid synergy. J. Pharmacol. Exp. Ther. 2002, 300, 282-290. [CrossRef]

40. Duflo, F.; Li, X.; Bantel, C.; Pancaro, C.; Vincler, M.; Eisenach, J.C. Peripheral Nerve Injury Alters the $\alpha 2$ Adrenoceptor Subtype Activated by Clonidine for Analgesia. Anesthesiology 2002, 97, 636-641. [CrossRef]

41. Quaglia, W.; Del Bello, F.; Giannella, M.; Piergentili, A.; Pigini, M. $\alpha 2$ C-adrenoceptor modulators: A patent review. Expert. Opin. Ther. Pat. 2011, 21, 455-481. [CrossRef]

42. Chilmonczyk, Z.; Bojarski, A.J.; Pilc, A.; Sylte, I. Functional selectivity and antidepressant activity of serotonin 1A receptor ligands. Int. J. Mol. Sci. 2015, 16, 18474-18506. [CrossRef] [PubMed]

43. Simon, N.G.; Guillon, C.; Fabio, K.; Heindel, N.D.; Lu, S.-f.; Miller, M.; Ferris, C.F.; Brownstein, M.J.; Garripa, C.; Koppel, G.A. Vasopressin antagonists as anxiolytics and antidepressants: Recent developments. Recent Pat. CNS Drug Discov. 2008, 3, 77-93. [CrossRef]

44. Narayen, G.; Mandal, S.N. Vasopressin receptor antagonists and their role in clinical medicine. Indian J. Endocrinol. Metab. 2012, 16, 183-191. [CrossRef] [PubMed]

45. Liu, X.; Luo, G.; Jiang, J.; Ma, T.; Lin, X.; Jiang, L.; Cheng, J.; Tao, R. Signaling through hepatocyte vasopressin receptor 1 protects mouse liver from ischemia-reperfusion injury. Oncotarget 2016, 7, 69276. [CrossRef] 
46. Glass, M.; Faull, R.; Dragunow, M. Cannabinoid receptors in the human brain: A detailed anatomical and quantitative autoradiographic study in the fetal, neonatal and adult human brain. Neuroscience 1997, 77, 299-318. [CrossRef]

47. Kano, M.; Ohno-Shosaku, T.; Hashimotodani, Y.; Uchigashima, M.; Watanabe, M. Endocannabinoid-mediated control of synaptic transmission. Physiol. Rev. 2009, 89, 309-380. [CrossRef]

48. Xu, X.; Liu, Y.; Huang, S.; Liu, G.; Xie, C.; Zhou, J.; Fan, W.; Li, Q.; Wang, Q.; Zhong, D.; et al. Overexpression of cannabinoid receptors $\mathrm{CB} 1$ and $\mathrm{CB} 2$ correlates with improved prognosis of patients with hepatocellular carcinoma. Cancer Genet. Cytogenet. 2006, 171, 31-38. [CrossRef] [PubMed]

49. Qamri, Z.; Preet, A.; Nasser, M.W.; Bass, C.E.; Leone, G.; Barsky, S.H.; Ganju, R.K. Synthetic cannabinoid receptor agonists inhibit tumor growth and metastasis of breast cancer. Mol. Cancer Ther. 2009, 8, 3117-3129. [CrossRef] [PubMed]

50. Ogden, S.B.; Malamas, M.S.; Makriyannis, A.; Eckel, L.A. The novel cannabinoid CB(1) receptor agonist AM11101 increases food intake in female rats. Br. J. Pharmacol. 2019, 176, 3972-3982. [CrossRef]

51. Kim, A.-R.; Lee, M.-S.; Choi, J.-W.; Utsuki, T.; Kim, J.-I.; Jang, B.-C.; Kim, H.-R. Phlorofucofuroeckol A suppresses expression of inducible nitric oxide synthase, cyclooxygenase-2, and pro-inflammatory cytokines via inhibition of nuclear factor- $\mathrm{kB}$, c-Jun $\mathrm{NH}$ 2-terminal kinases, and Akt in microglial cells. Inflammation 2013, 36, 259-271. [CrossRef]

52. Eo, H.J.; Kwon, T.H.; Park, G.H.; Song, H.M.; Lee, S.J.; Park, N.H.; Jeong, J.B. In Vitro Anticancer Activity of Phlorofucofuroeckol A via Upregulation of Activating Transcription Factor 3 against Human Colorectal Cancer Cells. Mar. Drugs 2016, 14, 69. [CrossRef] [PubMed]

53. D'Antona, A.M.; Ahn, K.H.; Kendall, D.A. Mutations of CB1 T210 produce active and inactive receptor forms: Correlations with ligand affinity, receptor stability, and cellular localization. Biochemistry 2006, 45, 5606-5617. [CrossRef] [PubMed]

54. Römpler, H.; Yu, H.-T.; Arnold, A.; Orth, A.; Schöneberg, T. Functional consequences of naturally occurring DRY motif variants in the mammalian chemoattractant receptor GPR33. Genomics 2006, 87, 724-732. [CrossRef] [PubMed]

55. Krishna Kumar, K.; Shalev-Benami, M.; Robertson, M.J.; Hu, H.; Banister, S.D.; Hollingsworth, S.A.; Latorraca, N.R.; Kato, H.E.; Hilger, D.; Maeda, S.; et al. Structure of a Signaling Cannabinoid Receptor 1-G Protein Complex. Cell 2019, 176, 448-458.e12. [CrossRef]

56. Lin, L.S.; Ha, S.; Ball, R.G.; Tsou, N.N.; Castonguay, L.A.; Doss, G.A.; Fong, T.M.; Shen, C.-P.; Xiao, J.C.; Goulet, M.T.; et al. Conformational Analysis and Receptor Docking of N-[(1S,2S)-3-(4-Chlorophenyl)-2-(3-cyanophenyl)-1-methylpropyl]-2-methyl2-\{[5-(trifluoromethyl)pyridin-2-yl]oxy\}propanamide (Taranabant, MK-0364), a Novel, Acyclic Cannabinoid-1 Receptor Inverse Agonist. J. Med. Chem. 2008, 51, 2108-2114. [CrossRef]

57. Turton, M.; O'shea, D.; Gunn, I.; Beak, S.; Edwards, C.; Meeran, K.; Choi, S.; Taylor, G.; Heath, M.; Lambert, P. A role for glucagon-like peptide-1 in the central regulation of feeding. Nature 1996, 379, 69-72. [CrossRef]

58. Drucker, D.J.; Nauck, M.A. The incretin system: Glucagon-like peptide-1 receptor agonists and dipeptidyl peptidase-4 inhibitors in type 2 diabetes. Lancet 2006, 368, 1696-1705. [CrossRef]

59. Kim, E.-A.; Lee, S.-H.; Lee, J.-H.; Kang, N.; Oh, J.-Y.; Ahn, G.; Ko, S.C.; Fernando, S.P.; Kim, S.-Y.; Park, S.-J. A marine algal polyphenol, dieckol, attenuates blood glucose levels by Akt pathway in alloxan induced hyperglycemia zebrafish model. RSC Adv. 2016, 6, 78570-78575. [CrossRef]

60. Paudel, P.; Seong, S.H.; Fauzi, F.M.; Bender, A.; Jung, H.A.; Choi, J.S. Establishing GPCR targets of hMAO active anthraquinones from Cassia obtusifolia Linn seeds using in silico and in vitro methods. ACS Omega 2020, 5, 7705-7715. [CrossRef]

61. Mohd Fauzi, F.; John, C.M.; Karunanidhi, A.; Mussa, H.Y.; Ramasamy, R.; Adam, A.; Bender, A. Understanding the mode-ofaction of Cassia auriculata via in silico and in vivo studies towards validating it as a long term therapy for type II diabetes. J. Ethnopharmacol. 2017, 197, 61-72. [CrossRef]

62. Paudel, P.; Seong, S.H.; Jung, H.A.; Choi, J.S. Characterizing fucoxanthin as a selective dopamine D3/D4 receptor agonist: Relevance to Parkinson's disease. Chem. Biol. Interact. 2019, 310, 108757. [CrossRef] [PubMed]

63. Goodsell, D.S.; Morris, G.M.; Olson, A.J. Automated docking of flexible ligands: Applications of AutoDock. J. Mol. Recognit. 1996, 9, 1-5. [CrossRef]

64. Granier, S.; Manglik, A.; Kruse, A.C.; Kobilka, T.S.; Thian, F.S.; Weis, W.I.; Kobilka, B.K. Structure of the $\delta$-opioid receptor bound to naltrindole. Nature 2012, 485, 400-404. [CrossRef] [PubMed]

65. Shao, Z.; Yan, W.; Chapman, K.; Ramesh, K.; Ferrell, A.J.; Yin, J.; Wang, X.; Xu, Q.; Rosenbaum, D.M. Structure of an allosteric modulator bound to the CB1 cannabinoid receptor. Nat. Chem. Biol. 2019, 15, 1199-1205. [CrossRef]

66. Song, G.; Yang, D.; Wang, Y.; de Graaf, C.; Zhou, Q.; Jiang, S.; Liu, K.; Cai, X.; Dai, A.; Lin, G.; et al. Human GLP-1 receptor transmembrane domain structure in complex with allosteric modulators. Nature 2017, 546, 312-315. [CrossRef] 